\title{
Geological Map of the Rocca Busambra-Corleone region (western Sicily, Italy): explanatory notes
}

\author{
LuCA BASILONE (*)
}

\section{ABSTRACT}

The geology of the Rocca Busambra-Corleone region, in centralwestern Sicily, is relevant to the understanding of the central sector of the Maghrebian-Sicilian fold-and-thrust belt.

In the investigated area Mesozoic shallow- and deep-water carbonate deposits pertaining respectively to the Trapanese and the Sicanian successions, and a thick Oligo-Miocene numidian flysch body, crop out. Minor outcrops of Cretaceous-Palaeogene Sicilide complex and syn-orogenic deposits of the Late Serravallian-Early Messinian Castellana Sicula and Terravecchia formations are also present.

A structural analysis reveals complex tectonic relationships between the Trapanese carbonate platform tectonic unit (the Rocca Busambra carbonate ridge) and the overthrusting Sicanian deepwater carbonate (Corleone-Barracù) and numidian flysch tectonic units, outcropping around the carbonate ridge.

In this tectonic frame Rocca Busambra is a $15 \mathrm{~km}$ long, E-Wtrending large antiform, slightly rotated to the NW-SE on its eastern limb (Pizzo Marabito). The unit forms a southerly verging ramp structure; it is bound, to the south, by E-W and WNW-ESE striking major reverse faults and, to the north, by the E-W striking Busambra fault that is a back-verging reverse fault characterized by right-handed strike-slip component of movement. The Busambra carbonate platform tectonic unit, that appears to have been thrust up to the surface, is reimbricated above the Sicanian deep-water carbonate and numidian flysch tectonic units; these, in turn, are redeformed. The latter tectonic event overprinted the original tectonic relationships and took place during the Late Pliocene, as evidenced in adjacent regions.

KEY WORDS: Western Sicily, geological survey and mapping, Mesozoic shallow- and deep-water carbonate successions, tectono-stratigraphic setting, Meso-Cenozoic deformational history.

\section{INTRODUCTION}

The Rocca Busambra-Corleone region (fig. 1a), located in the Belice valley between the southern Palermo Mountains and the north-western Sicanian Mountains, is a very complex area of the Western Sicily fold-and-thrust belt (from now on named FTB).

The first detailed study carried out in the region is due to MASCLE (1979), who compiled a geological map ( $1: 100,000$ scale) of the whole Sicanian Mountains region; the related explanatory notes are an important support to the geological knowledge of the area.

CATALANO \& D'ARgENio (1978; 1982a) and CATALANO \& MONTANARI (1979) proposed a tectonic framework of western Sicily with a concise description of the stratigraphy. These authors distinguished the main structuralstratigraphic units and their geometric relationships.

(*) Dipartimento di Geologia e Geodesia, Università di Palermo, Via Archirafi, 20-22 - 90123 Palermo. lucabasilone@unipa.it
Several other studies have been carried out to describe the stratigraphy of the area (WENDT, 1963-1971; MASCLE, 1973, 1979; MARTIRE et alii, 2002; BASILONE, 2009) and its structural setting (ROURE et alii, 1990; LENTINI et alii, 1994; AgATE et alii, 1998a; CATALANO et alii, 1998, 2010a, b; NigRo \& RENDA, 1999; 2001; MonACO et alii, 2000). As a consequence, several and controversial interpretations, concerning both the stratigraphic and the tectonic setting of the Rocca Busambra-Corleone region, grew up.

In spite of the previous and thorough work about the stratigraphy and the tectonics of the study area, no detailed scaled field mapping has yet been compiled.

Regional studies in the frame of the CARG project in Western Sicily (Carta Geologica d'Italia, 1:50,000 scale) have led the present Author to collect new field and analytical data with the aim of compiling a detailed geological map of the Rocca Busambra-Corleone area. The field work carried out at a 1:10,000 scale is assembled and presented on a base-map at a 1:37,500 scale. The main results concerning the geological knowledge of the region, the stratigraphic and structural features are illustrated in the present explanatory notes.

The present work is an attempt to give detailed field map support to some new insight concerning the structural evolution of the region in the frame of the Sicilian FTB. The geology of the area is particularly valuable to the understanding of the tectono-sedimentary evolution of the Mesozoic Sicilian continental margin and the Cenozoic-Quaternary deformational history (including thin-skinned and later envelopment thrusting).

\section{GEOLOGICAL FRAMEWORK OF WESTERN SICILY}

Western Sicily is a part of the Maghrebian Sicilian FTB, a segment of the Alpine collisional belt, recently described (CATALANO et alii, 2000 and reference therein) as a result of both post-collisional convergence between Africa and Europe and roll-back of the subduction hinge of the Ionian lithosphere (fig. 1b on the frame of the map).

The western Sicilian FTB (fig. 1a) is the result of the piling up of tectonic units derived from the deformation of distinct ancient paleogeographic domains. The latter were developed, during the Meso-Cenozoic, in the Sicilian sector of the southern Tethyan continental margin (Bernoulli \& Jenkins, 1974; Catalano \& D'ARgenio, 1978; STAMPFLY \& BOREL, 2002).

The tectonic edifice is characterized by the occurrence of three main structural levels (fig. 1b), from the bottom, consisting of: a) imbricated slices of carbonate 
platform tectonic units (Panormide, Trapanese and Saccense domains); $b$ ) a wedge of deep-water carbonate thrust sheets (Imerese and Sicanian units); $c$ ) the Sicilidi nappes and the numidian flysch units, detached from their substrate. These tectonic units are overlain by wedge-top basins, filled by Miocene-Lower Pleistocene clastic deposits, evaporites and carbonates.

The tectonic emplacement took place during the Miocene-Early Pleistocene time interval. It is commonly assumed that a $\mathrm{S}$ and ESE verging thrust propagation (CATALANO \& D'ARGENIO, 1982a) accompanied by clockwise rotations (CHANNELl et alii, 1990; OLDOw et alii, 1990) and deep-seated thrust planes with strike-slip component of movements (GHISETTI \& VEZZANI, 1984) occurred. The deeper rock successions have been detached from their substrate from these faults, forming axial culminations and ramp structures (OLDow et alii, 1990; CAtAlano et alii, 1998, 2010a; Avellone et alii, 2010).

\section{MAPPING METHODOLOGIES}

Field mapping was carried out using published base maps (Carta Tecnica Regionale of the Regione Siciliana) at a 1:10,000 scale. Satellite and aerial images were analyzed in order to recognize the main morphostructural features. The geological map is presented at a scale of 1:37,500 in a Transverse Mercator Projection.

Lithostratigraphic criteria and facies analyses were used to distinguish 22 formations. The detailed reconnaissance is also supported by paleontologic analyses. The carbonate deposits were investigated also using petrographical and sedimentological analyses; the resulting lithofacies were biostratigraphically calibrated, mostly based on Jurassic ammonite biozonation (WENDT, 1969), calpionellids biozonation (ALLEMAN et alii, 1971), and Cretaceous-Miocene calcareous plankton biostratigraphy (CARON, 1985; IACCARINO, 1985; PERCH-NIELSEN, 1985; ForNACIARI et alii, 1996; FORESI et alii, 2001; SPROVIERI et alii, 1996, 2002).

Field mapping was integrated with structural analyses at a map and mesoscopic scale.

Field results, calibrated by seismic profiles interpretation (CATALANO et alii, 1998; 2000), allow us to recognize the spatial continuity of the rock bodies at depth and the structural setting of the study region.

\section{THE GEOLOGICAL MAP}

The map includes:

a) a northern sector, characterized by the Rocca Busambra carbonate ridge and its western continuation (Rocca Argenteria, Rocca del Drago), a $15 \mathrm{~km}$ long E-W oriented complex morphostructure, made of MesozoicMiocene shallow-to-pelagic carbonate succession (Trapanese paleodomain);

b) a south-western sector, around the Corleone town, where the Cretaceous-Miocene carbonate and clastic deposits, pertaining to the Sicanian deep-water succession, outcrop;

c) an eastern and northernmost sector (GodranoFicuzza region), where the Oligo-Miocene numidian flysch deposits prevail;

d) minor outcrops of Sicilide deposits, are mapped in the north-westernmost corner;

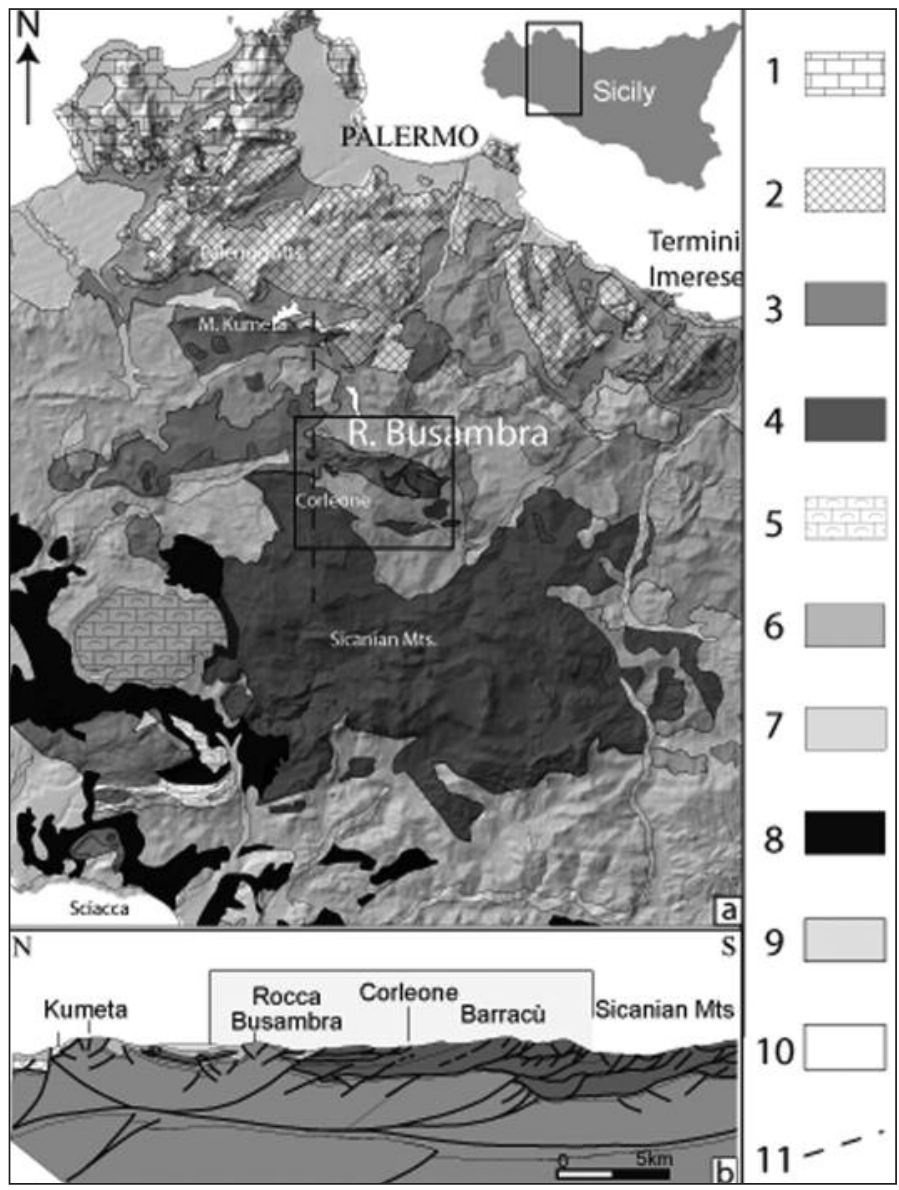

Fig. 1 - a) Structural map of central-western Sicily (modif. from CATALANO et alii, 2004); b) Regional geoseismic profile (modif. from CATALANO et alii, 2000), across the central sector of the western Sicily fold and thrust belt, showing the main tectonic features. LEGEND: 1) Panormide carbonate platform tectonic units; 2) Imerese basin tectonic units; 3) Trapanese-Saccense pelagic platform tectonic units; 4) Sicanian basin tectonic units; 5) M. Genuardo carbonate platform-to-basin tectonic unit; 6) Numidian flysch tectonic units 7) Miocene syn-tectonic deposits; 8) Miocene-Pliocene deposits; 9) Pleistocene deposits; 10) study area; 11) trace of the regional geoseismic profile of fig. $1 \mathrm{~b}$

e) Miocene foredeep clastic rocks, largely outcropping in the south-western area.

\section{GEOMORPHOLOGIC OUTLINE}

The geomorphologic configuration of the study region can be summarized in two different landscape types, related to the outcropping lithologies and to the prevailing morphogenetic processes.

The carbonate highland landscape (Rocca Busambra ridge $1613 \mathrm{~m}$ a.s.l.) shows geomorphic forms due to tectonics and morphoselection, such as the several palaeosurfaces, and the wide, structurally controlled, scarps, hundreds of metres high. In the Contrada Giardinello (south of Rocca Busambra ridge on the map), the large block movements and the E-W oriented opening trenches and fractures suggest deep-seated gravitational slope deformation (AGNESI et alii, 1978). These phenomena originate mass rock movements of more than $500.000 .000 \mathrm{~m}^{3}$. The landslides have masked the original tectonic relationships between the outcropping tectonic units. 

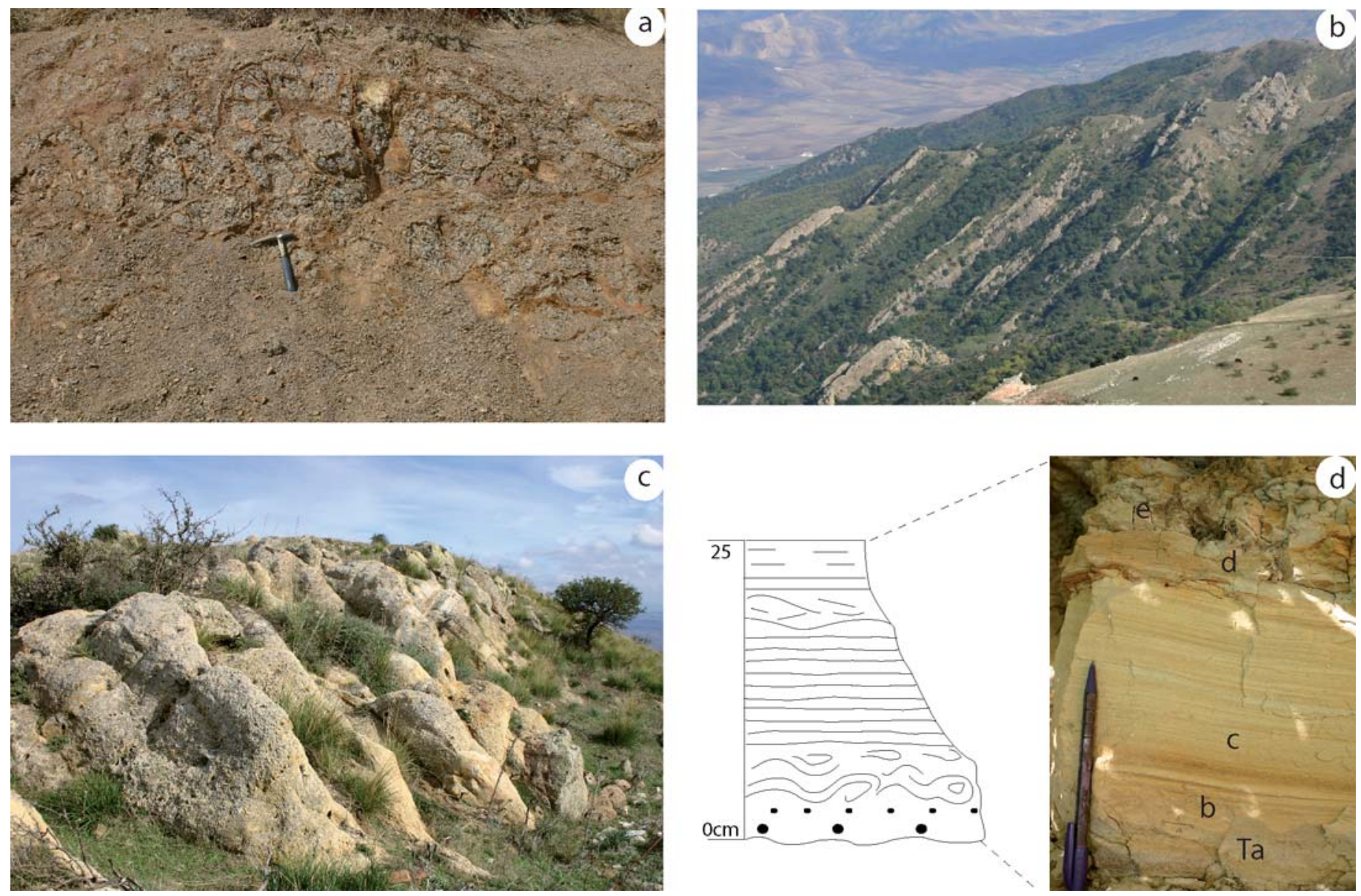

Fig. 2 - The numidian flysch lithofacies: $a$ ) shales (Portella Colla mb) with iron-manganiferous crusts (Pizzo Candreo); $b$ ) hectometres turbiditic succession of the Geraci Siculo mb (Bosco della Ficuzza); c) massive thick-bedded coarse and well-rounded quartz-conglomerates, alternated with yellow fine-sandstones with parallel and oblique lamination; $d$ ) detail of a turbiditic bed: Ta) graded conglomerates, b) chaotic coarse sandstones, c) sandstones with normal gradation and parallel lamination, d) laminated mudstones and e) greenish clays.

The marly clayey hilly landscape consists of gentle reliefs with low, inclined slopes, where landslide phenomena and water processes prevail. The mapped landslides, mostly due to a rotational creep, are both active and inactive (no recent movements in the last few decades). The largest landslide bodies are more than $2 \mathrm{~km}$ long and $1 \mathrm{~km}$ in length, and some tens of metres thick. Spectacular examples are mapped in the region sited to the south of Monte Cardellia, where clayey deposits (Cardellia marls), embedded between two limestone levels («Corleone calcarenites» and Amerillo Fm), are repeatedly mobilized.

Fluvial processes originate several orders of alluvial terraces (mapped along the main rivers) and spectacular erosional canyons in the Corleone town area, where also lateral spreading phenomena occur.

\section{LITHOSTRATIGRAPHY AND FACIES ANALYSIS}

The outcropping lithostratigraphic units (fig. 2 on the frame of the map) will be described in descending order, starting from those pertaining to the highest structural units in the study sector. The description is accom- panied by some illustrations (figs. 2-9) and summary tables (tabs. 1-4), concerning the main lithostratigraphic, environmental and paleontological features of the formations. The stratigraphic columns presented in figs. 3 and 9 show detailed sequences of the Monte Barracù and Rocca Busambra successions. The following paragraphs describe the individual rock units in some detail.

\section{SICILIDE DEPOSITS}

The Sicilide terrains, a few tens of metres thick, outcrop, as scattered patches, at Case Bifarera, Cozzo Arcuri and Masseria Nicolosi (northern sector of the map), where the rocks tectonically overlie the numidian flysch deposits. They include Late Cretaceous varicoloured silicified clays, shales and marls of the "varicoloured clays» (AVF on the map) and Middle-Late Eocene white pelagic limestones (Polizzi Formation, POZ on the map, tab. 1), with intercalations of graded and laminated packstonewackestone rich in benthic macroforaminifers, pectinids, Corallinacean algae, crinoid and echinoid fragments (tab. 1). The mudstone-wackestone beds show bioturbation (ichnofacies with Palaeodictyon isp., Nereites isp., Helminthoida isp.) and, locally, volcanoclastic layers (Contrada Bifarera). 
TABLE 1

Lithostratigraphic characters of the Sicilidi deposits and numidian flysch formation.

\begin{tabular}{|c|c|c|c|c|c|c|}
\hline \multicolumn{4}{|c|}{ Main lithology } & \multirow{2}{*}{ 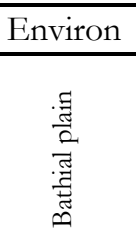 } & \multirow{2}{*}{$\begin{array}{l}\text { Fossils content } \\
\text { Planktonic forams (Rotalipora appenninica, R. brotzeni and R. reicheli } \\
\text { biozones) and calcareous nannofossils (CC 25-26) }\end{array}$} & \multirow{2}{*}{ 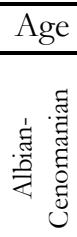 } \\
\hline $\begin{array}{l}\text { Varic } \\
\text { clays }\end{array}$ & $\begin{array}{l}\text { loured } \\
\text { AVF) }\end{array}$ & $\begin{array}{l}\text { Varicoloured silicized clays, chaotic } \\
\text { shales, mudstone and packstone } \\
\text { intercalations }\end{array}$ & 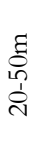 & & & \\
\hline $\begin{array}{l}\text { Poliz } \\
\text { (PO' }\end{array}$ & & $\begin{array}{l}\text { White pelagic limestones wirh } \\
\text { ichnofacies (Palaeodictyon isp., Nereites } \\
\text { isp., Helminthoida isp.), graded and } \\
\text { laminated packstone intercalations. } \\
\text { Volcanoclastic layers (C.da Bifarera) }\end{array}$ & 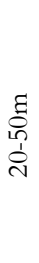 & 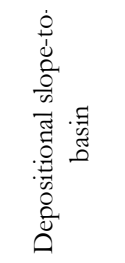 & $\begin{array}{l}\text { Planktonic forams (Hantkenina nuttall, Truncorotaloides rohri, } \\
\text { Globigerinatheka semïnvoluta, Turborotalia cerroazulensis s.l. } \\
\text { biozones) and calcareous nannofossils (NP } 20 \text { biozone). } \\
\text { Nummulitids, alveolinids, discocyclinids, pectinids, } \\
\text { corallinacean algae, crinoid and echinoid fragments in the } \\
\text { resedimented beds }\end{array}$ & 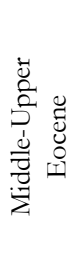 \\
\hline 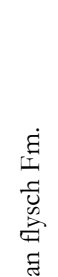 & 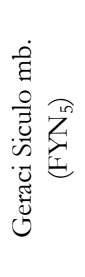 & $\begin{array}{l}\text { Megabeds of well-cemented quartz } \\
\text { turbidite sandstones; pebbly } \\
\text { conglomerates, some metres-thick, } \\
\text { with darkish mudstone intraclasts, are } \\
\text { locally interlayered }\end{array}$ & 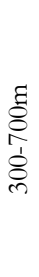 & 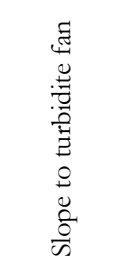 & $\begin{array}{l}\text { Planktonic forams (Globigerinoides trilobus, Globoquadrina dehiscens } \\
\text { dehiscens-Catapsydrax dissimilis biozones), calcareous nannofossils } \\
\text { (MNN } 1 \text { and MNN2b) and arenaceous foraminifers } \\
\text { (Ammodiscus spp., Cyclammina spp., Trochammina spp.) }\end{array}$ & 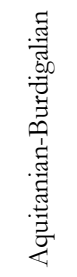 \\
\hline Z & 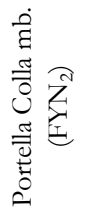 & $\begin{array}{l}\text { Brown manganesiferous laminated } \\
\text { clays, graded and laminated quartz } \\
\text { sandstone (FYN2a) intercalations. }\end{array}$ & 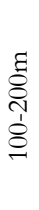 & $\begin{array}{l}\frac{\tilde{O}}{0} \\
\frac{0}{1} \\
\dot{1} \\
0 \\
0 \\
0 \\
\frac{\tilde{0}}{0} \\
\frac{0}{\infty}\end{array}$ & $\begin{array}{l}\text { Planktonic forams (Globorotalia opima opima, Globigerina ciperoensis } \\
\text { ciperoensis, Globoquadrina debiscens dehiscens-Catapsydrax dissimilis } \\
\text { biozones) and calcareous nannofossils (NP 24-25, MNN 1b) }\end{array}$ & 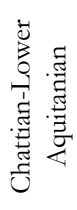 \\
\hline
\end{tabular}

\section{NUMIDIAN FLYSCH DEPOSITS}

The numidian flysch formation consists of Upper Oligocene-Lower Miocene clays and shales with thick turbiditic quartz-sandstone and conglomerate intercalations (fig. 2). The unit, more than $800 \mathrm{~m}$-thick, widely outcrops both in the northern and eastern sector of the map, where it tectonically overlies the Sicanian rock unit. The terrigenous wedge lacks of its original Mesozoic-Eocene carbonate substrate, found elsewhere. The formation is made up of two members (tab. 1).

The Portella Colla member $\left(\mathrm{FYN}_{2}\right.$ on the map) consists of 100-200 m-thick brown manganiferous laminated clays (fig. 1a), locally scaly, with m-thick yellowish siltstones and fine-graded and laminated quartz-sandstone intercalations; it outcrops at Nicolosi, Scalilli, Bifarera, Madonna di Tagliavia areas (north-western sector of the map) and at Pizzo Candreo (few metres). Planktonic foraminifers and nannoplankton content suggest a Chattian-Lower Aquitanian age.

The Geraci Siculo member $\left(\mathrm{FYN}_{5}\right.$ on the map) consists of an upward thickening turbiditic sequence (fig. 2b). The recognized lithofacies are: a) massive thick-bedded conglomerate (fig. 2c) alternated with yellow-reddish fine-to-coarse planar- and oblique-laminated sandstone. The conglomerate layers, with erosional lower boundary are coarse and well-rounded quartz grains; $b$ ) siliceous sandstones, commonly with erosional lower boundary, and complete turbiditic facies sequences (fig. 2d); mudsupported texture pebbly conglomerate, ten metres-thick, with darkish mudstone intraclasts, are locally inter- layered. The Geraci Siculo member is well-exposed in the Bosco della Ficuzza, Bosco del Cappelliere, Marosa and Cozzo Donna Giacoma areas (eastern and southern sector of the map). It is dated as Lower Miocene (based on planktonic foraminifer and nannofossil biostratigraphy, tab. 1).

\section{INCERTAE SEDIS DEPOSITS}

At Contrada Bicchinello (south of Pizzo Nicolosi), a small rock body of Eocene breccias and bioclastic packstone-grainstone with benthic macroforaminifers (nummulitids, alveolinids), crustacean and bivalve fragments (Bicchinello limestone, PUN on the map), crops out. These deposits are believed to be the remnants of tectonic slices pertaining to the Prepanormide tectonic units (CATALANO et alii, 2010a and reference therein).

\section{SiCANIAN DOMAIN DEPOSITS}

The whole Sicanian succession is well exposed at Monte Barracù, immediately to the south of the study region (MASCLE, 1979; AGATE et alii, 1998b), as shown by the detailed stratigraphic column (fig. 3). Its depositional characteristics point to a deep-water Triassic-Miocene paleodomain. In the study area only some lithostratigraphic units are mapped (tab. 2):

a) Mufara Formation (MUF on the map). Late Triassic (Carnian) thin-bedded laminated grey mudstone and darkyellowish marls, with halobids, ammonites, radiolarians, 


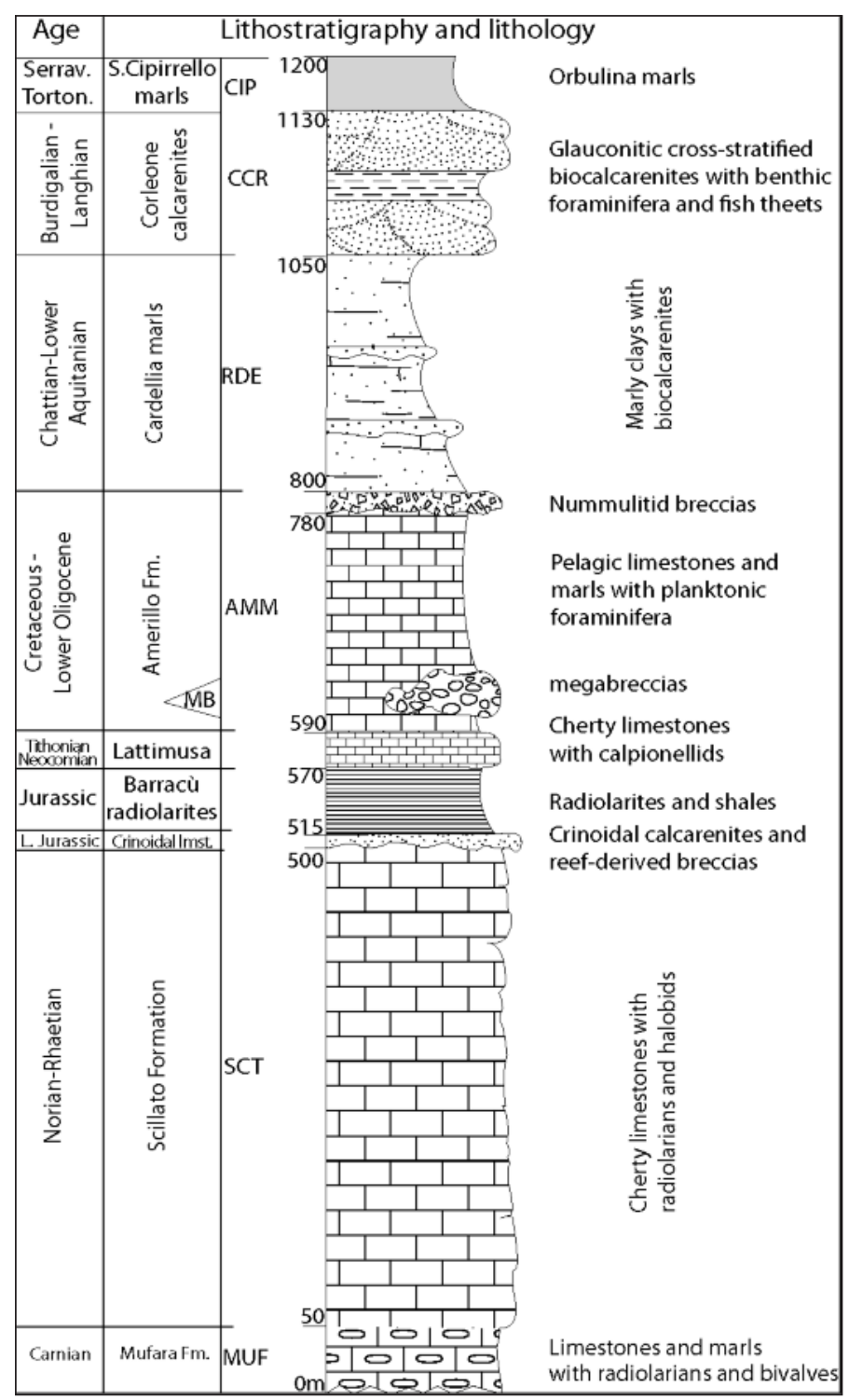

Fig. 3 - Triassic-Miocene deep-water Sicanian stratigraphic succession, measured and sampled along the Monte Barracù natural section.

conodonts, palinomorphs, gastropods and rare arenaceous foraminifers. It outcrops, 10-30 m thick, at Masseria Cicio, Masseria del Casale, Puntale l'Ape, Masseria Nicolosi and Cozzo Tondo. The beds are strongly folded and faulted;

b) Hybla Formation (HYB on the map). Lower Cretaceous grey-blackish thin-bedded cherty limestones with radiolarians, sponge spiculae and planktonic foraminifers (fig. 4a), whitish marls rich in belemnites (Duvalia lata BLAINVILLE) and mollusc shells. Coarse-grained packstone with Aptychus fragments, are interlayered. The unit is mapped along the Rocca Busambra ridge in the Contrada Giardinello (south of Pizzo Marabito), where in spite of the strong deformation (folds and faults), it is up to 50 metres thick; its lower boundary does not outcrop on the map.

c) Amerillo Fm (AMMa-d on the map, fig. 5). The formation is Upper Cretaceous-to-lower Oligocene reddishto-whitish thin limestones and marly limestones (figs. 5a, b) with planktonic foraminifers (fig. 4b), limestones with ichnofacies (fig. 5c) and calcareous turbidites with macroforaminifers (fig. $5 \mathrm{~d}$ and fig. $4 \mathrm{c}$ ). Carbonate megabrec- cias (AMMm on the map) occur in beds in the Campanian-Lower Maastrichtian interval of the pelagic suc- cession. They are well-cemented sub-rounded cobbles and boulders deriving from the break up of the upper Triassic-Jurassic peritidal limestones and pelagic deposits.

The Amerillo Fm, 200 m-thick, outcrops at Portella del Vento, Piano della Tramontana, Contrada Giardinello, Casale and Pirrello (south-eastern side of the Rocca Busambra ridge), where the lithofacies described above are identified and mapped. These deposits, previously interpreted as pertaining to the Trapanese domain (GIUNTA \& LigUORI, 1975; MASCLE, 1979), appear well correlated with the typical Sicanian Amerillo Fm outcropping at Monte Barracù (southern edge of the map).

d) Cardellia marls (RDE on the map). Chattian-Lower Aquitanian marls and dark-green marly clays with iron nodules are rich in calcareous plankton; benthic macroforaminifers (nummulitids and Nephrolepidina spp.) bearing turbidite packstone (fig. 4d) are interlayered. These beds, 100-200 m-thick, conformably follow the Amerillo Fm. The recently proposed "Cardellia marls» formation outcrops at Contrada Bifarera (northwestern corner of the map, see also MASCLE, 1979), at Contrada Casale and Pirrello (southern side of Rocca Busambra), around the town of Corleone and at Monte Cardellia, where the proposed type section (fig. 6) is based on the biostratigraphic study of BIOLZI (1985).

e) Corleone calcarenites (CCR on the map). Lower Miocene glauconitic grainstone and packstone with benthic macroforaminifers (figs. 4e, f), calcareous and quartz-sandstones and greenish silty marls, unconformably follow. The lower boundary of the unit is a sharp and ero- sional unconformity surface above the Cardellia marls, as seen along the Monte Cardellia section (see fig. 6). The «Corleone calcarenites», 20-80 m-thick, outcrop at Cozzo Zuccarone-Cozzo Rubino anticline and, with maximum thickness, at Monte Cardellia and in the Corleone town, where the Rocca dei Maschi natural section was analyzed and sampled with detail to propose the type section of the formation. The measured succession (fig. 7), 70 metres thick, yellow and green in colour due to the occurrence of abundant glauconite minerals, consists of cyclic alternations of quartzglauconitic sandstones and bioclastic packstone in dm-thick beds with green marls. Several lithological intervals can be evidenced due to the composition of the beds and their erodible features; the succession is organized at least in two $3^{\text {rd }}$ order transgressive-regressive cycles.

f) San Cipirello marls (CIP on the map). Upper Serravallian-Lower Tortonian grey and sky-blue clays, clayey marls and sandy marls with rich planktonic content, 50-150 m-thick. The marls outcrop at Cozzo Zuccarone, Contrada Pirrello, Sant'Ippolito and Vallone del Poggio (Corleone town area), where conformably overlay, with a sharp surface, the "Corleone calcarenites».

The lower portion of the Sicanian succession (Scillato Fm, oolitic calcarenites and Prizzi breccias, Barracù radiolarites and Lattimusa, fig. 3) does not outcrop in the study region. Seismic profile interpretation and subsurface data suggest these rocks are presently buried in the region (CATALANO et alii, 1998; 2004).

\section{TRAPANESE CARBONATE PELAGIC-PLATFORM DEPOSITS}

The Rocca Busambra rocks pertain to the Meso-Cenozoic Trapanese paleogeographic domain (CATALANO \& 
TABLE 2

Lithostratigraphic characters of the Cretaecous-Miocene formations of the Sicanian succession.

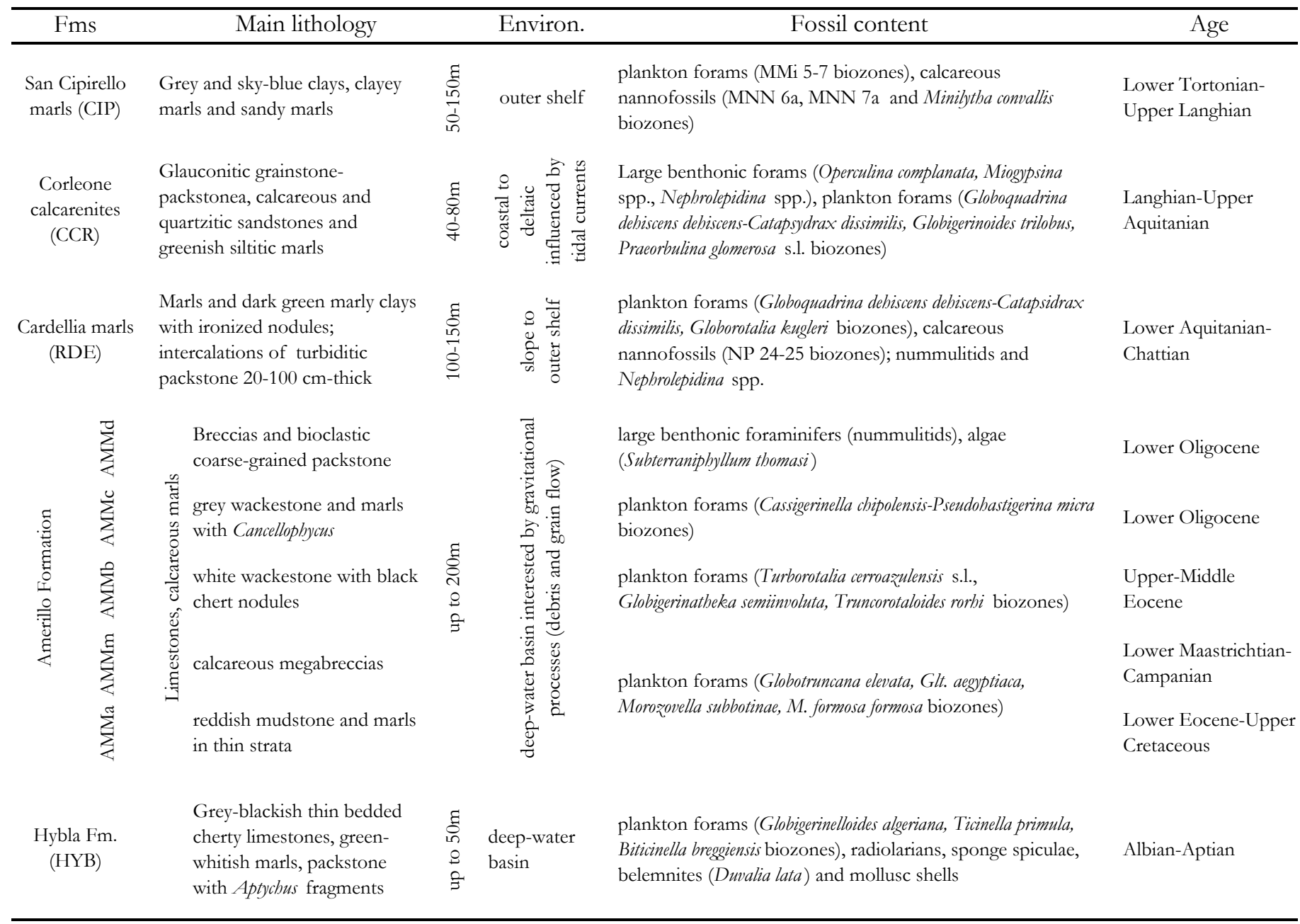

D'ARGENIO, 1978), where shallow marine and pelagic carbonate platform deposited progressively. The typical condensed sedimentation and facies variability of the Jurassic-Cretaceous deposits have been already investigated (Christ, 1960; TAMAJO, 1960; WENDT, 1963-1971; JENKYNS, 1970a; MARTIRE \& BERTOK, 2002; Basilone, 2007), as well the tectono-sedimentary features of the Jurassic-Cretaceous deposits exposed at the Piano Pilato sector (WENDT, 1971; GIUNTA \& LigUORI, 1975; MASCLE, 1973, 1979; Gullo \& Vitale, 1986; MartiRe \& MoNTAGNINO, 2002; BERTOK \& MARTIRE, 2009).

Tectono-stratigraphic features, such as paleofaults, buttress unconformity relationships, a dense network of neptunian dykes with several infilling generations and several large hiatuses, have been recently discussed as useful constraints to the palinspastic restoration of the Jurassic-to-Miocene tectono-sedimentary evolution of the Rocca Busambra (BASILONE, 2009).

The succession starts with: well-exposed Upper Triassic-Lower Jurassic carbonate shallow marine deposits which form the main bulk of the Rocca Busambra carbonate ridge. They include:

a) Marabito limestones (ITO on the map). Dolomitized upper Triassic sponge-bearing reef limestones (figs. $8 \mathrm{a}, \mathrm{b}$ and tab. 3), 30 metres thick, outcropping in the easternmost sector of the Rocca Busambra (Pizzo Marabito);

b) Inici Formation (INI on the map). White peritidal limestones, up to $400 \mathrm{~m}$ thick, display different shallowwater lithofacies (figs. 8c, d) organized in shallowing upward sequences. The fossil content (tab. 3) dates these beds to the Hettangian-Sinemurian time interval. The top of the white peritidal limestones appears to be dissected by a dense network of neptunian dykes. Impressive examples of these neptunian dykes are seen in the Rocca Argenteria quarry, where WENDT (1971) has restored the chronological evolution of the filling sediments. A regional unconformity marks the top of the Inici Formation which is capped by a blackish Fe-Mn crust. The latter is interpreted as an hardground related to the carbonate platform drowning (JENKYNS, 1970a) and due to probable anoxic events and bioerosion (DI STEFANO \& MindSZENTY, 2000);

c) the Inici Fm limestones are unconformably followed by the Jurassic condensed deposits of the Buccheri Fm. This unit includes two members:

i) Bositra limestones $\left(\mathrm{BCH}_{1}\right.$ on the map). A few metres thick, reddish-brown to grey wackestone/packstone (figs. 8e, f) and local laminitic stromatolites with rich pelagic fauna (tab. 3) of Bajocian-Early Kimmerid- 

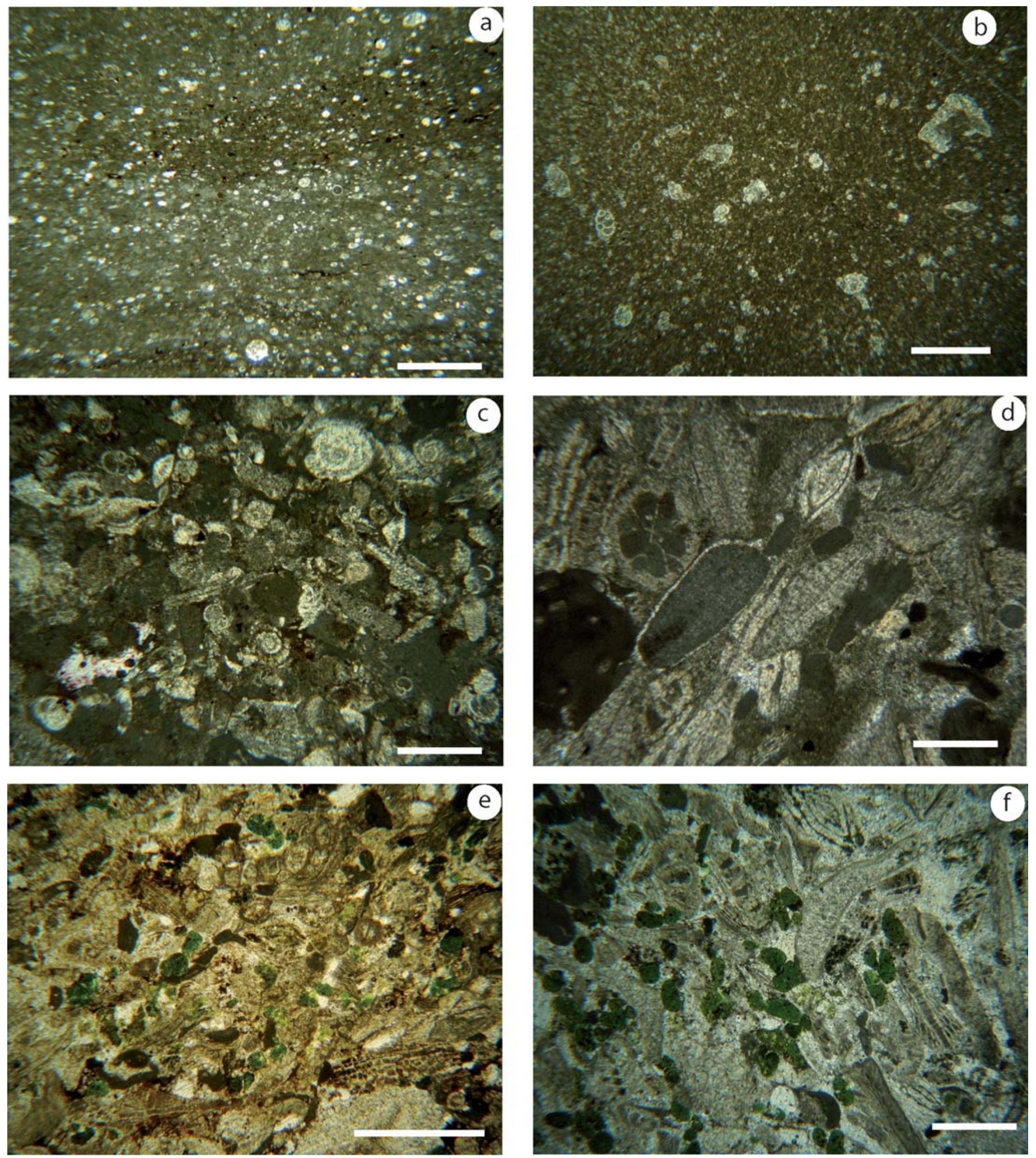

Fig. 4 - Microfacies of the Cretaceous-Miocene deposits of the Sicanian succession: $a$ ) mudstone with radiolarians, planktonic foraminifers and sponge spiculae (Hybla Formation, Contrada Giardinello, scale bar 1mm); $b$ ) wackestone with globotruncanids and heteroelicids (scaglia rossa lithofacies, Amerillo Formation, Piano della Tramontana, scale bar 1mm); c) packstone with benthic macroforaminifers, calcareous algae, corals and intraclasts (nummulitid breccias lithofacies of the Amerillo Formation, Monte Barracù, scale bar $1 \mathrm{~mm}$ ); $d$ ) packstone with benthic macroforaminifers, coral fragments and intraclasts (calcareous turbidite intercalations in the Cardellia marls, Contrada Pirrello, southern limb of Rocca Busambra, scale bar 1mm); $e$ ) and $f$ grainstone with benthic foraminifers, algae fragments, intraclasts and glauconitic grains (Corleone calcarenites, Rocca dei Maschi, scale bar 1mm). 
Monte Barracù section $\left({ }^{\circ}\right) \quad$ Portella del Vento section $\left({ }^{*}\right)$

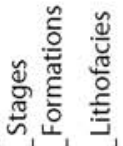

岗

.

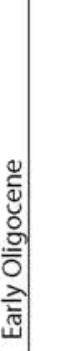

:

㫕

峁

它

을

$\frac{\bar{U}}{\varepsilon}$
$\frac{\mathrm{c}}{4}$

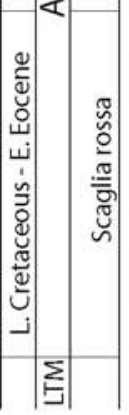

Key

Grey clayey marls

監 Limestones

Marly clays

Nummulitid breccias

20.5.

Marly limestones

[0] Calcareous megabreccias

- Parallel stratification/

= lamination

a* Cross stratification

lamination

w. Oblique stratification/ lamination

RDE Cardellia marls (Chattian-Aquitanian)
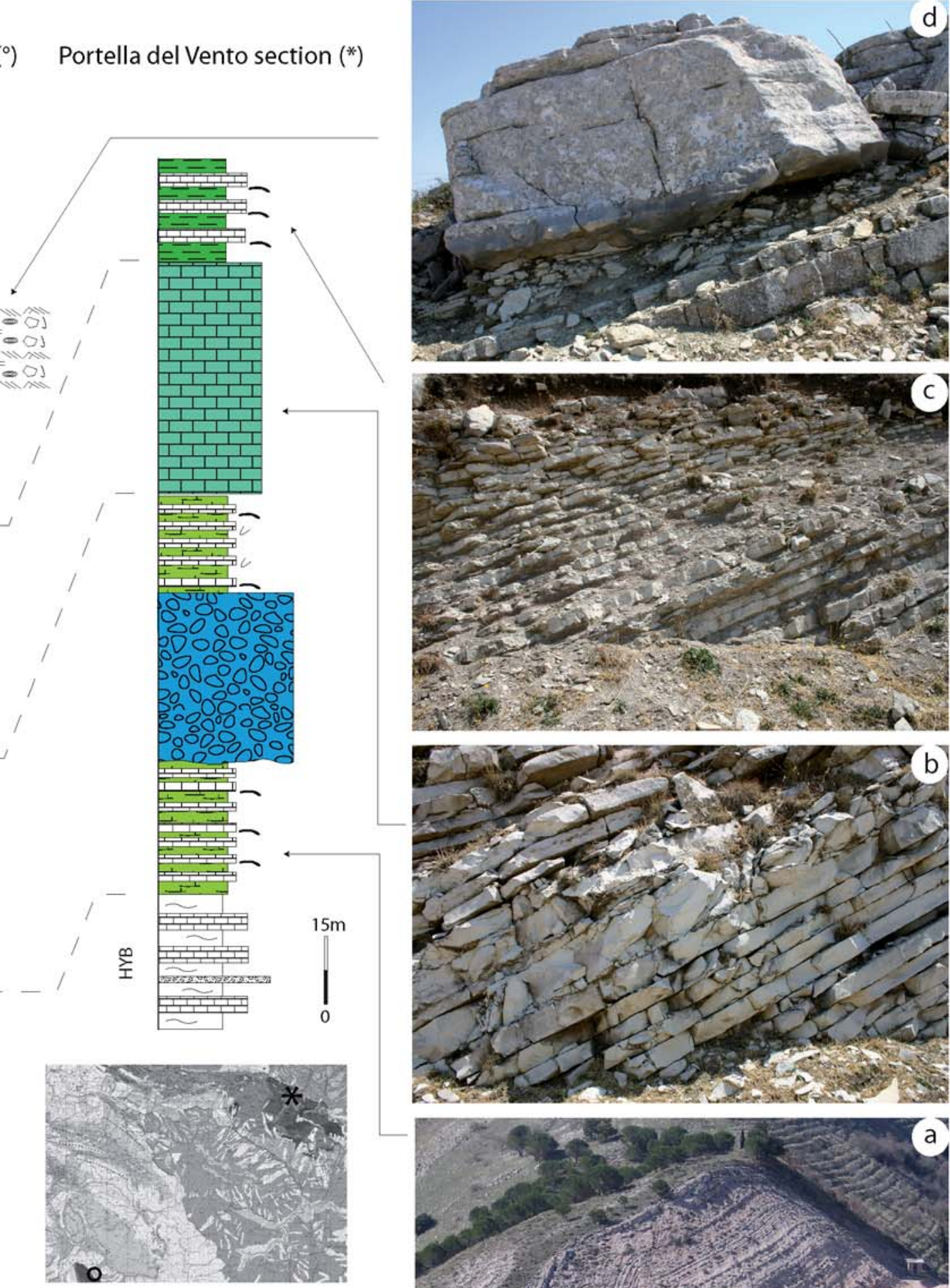

؛ Normal grading

- Benthic foraminifera

j Bioclasts $\&$ Burrows

Algae $\sim$ Traces Lattimusa

LTM (Tithonian-Valanginian)

HYB Hybla Formation

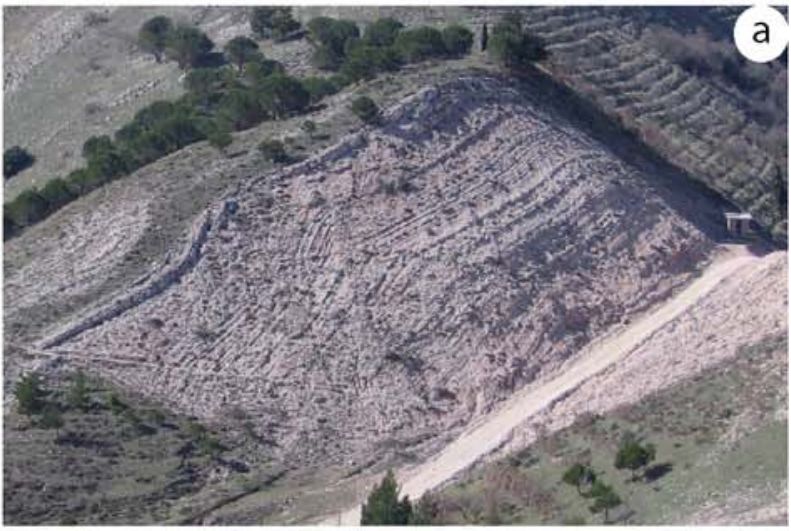

Fig. 5 - Comparison between the Sicanian Amerillo Fm outcropping at Monte Barracù and Piano della Tramontana (eastern Rocca Busambra ridge, see location map). Impressive characters of the main lithofacies are shown: $a$ ) strongly deformed reddish limestones and marls (red scaglia lithofacies, Portella del Vento, Rocca Busambra); b) thin white cherty limestones (white scaglia lithofacies, Monte Barracù); c) rhythmic alternations of thin grey limestones with ichnofacies (Cancellophycus isp.) and greenish marly clays (Monte Barracù); d) calcarenites and breccias with nummulitids (Monte Barracù); the m-thick resedimented bodies show erosional lower boundary, parallel and oblique lamination and gradational structures. 

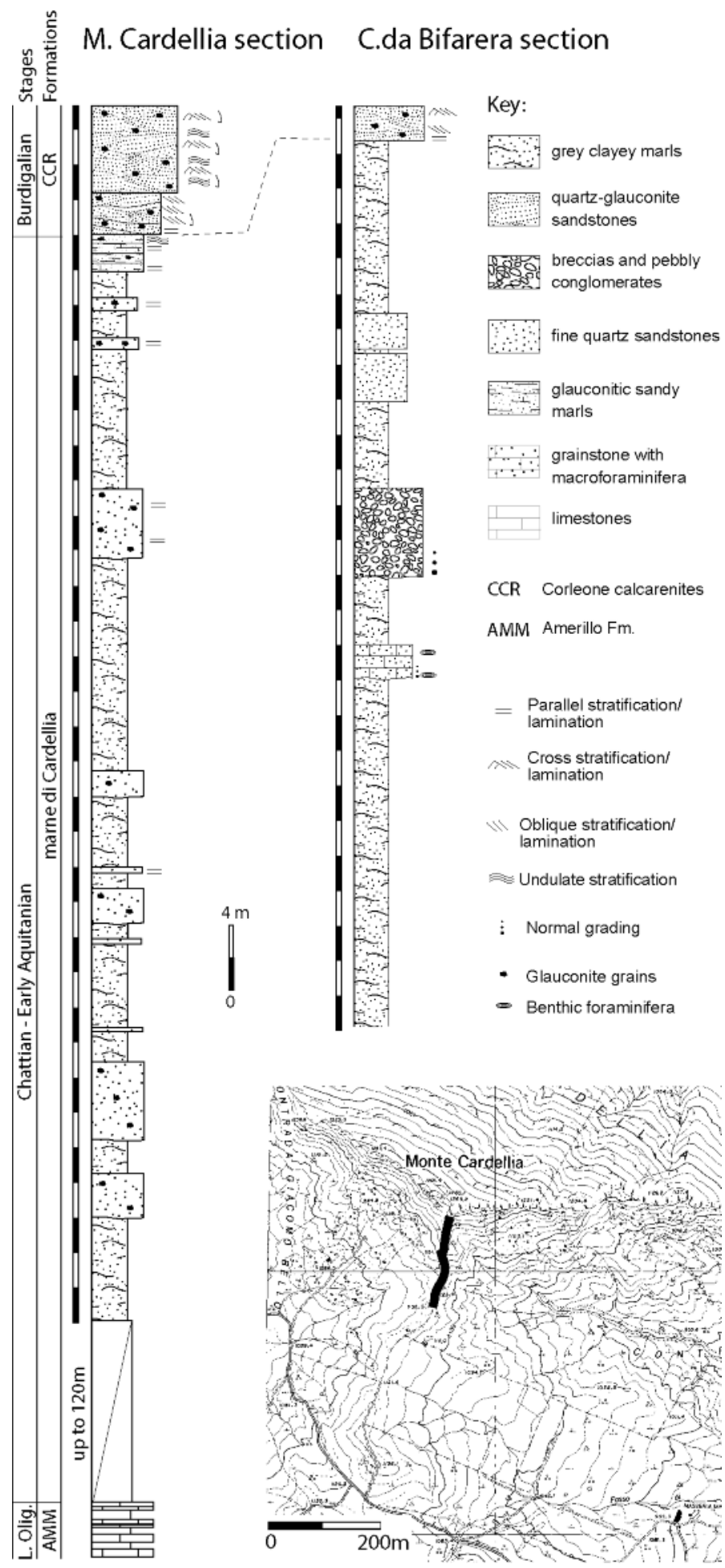

Fig. 6 - Detailed stratigraphic sections of the Cardellia marls, measured and sampled along the Monte Cardellia proposed type section (see location map) and Case Bifarera outcrop (north of Rocca Busambra).

gian age (WENDT, 1969). They outcrop mostly in the Piano Pilato region. This lithofacies is easily recognized by the dark dm-sized nodules that are encrusted by ferromanganese oxides (WENDT, 1963; JENKYNS, 1970b, 1971) and the interlayered cm-sized dark Fe-Mn crusts;

ii) Saccocoma limestones $\left(\mathrm{BCH}_{3}\right.$ on the map) are thickbedded, tabular and massive red-to-grey pelagic crinoid- bearing grainstone-packstone, a few metres thick, outcropping along the whole ridge. The rich fossil content (tab. 3) dates these beds to Late Kimmeridgian-Tithonian age;

d) crinoidal limestones (RND on the map) include red-to-grey massive grainstone-packstone, 50-80 cm thick, in places encrusted by Fe-Mn layers; they are, locally, the basal sediments of the Buccheri Fm.

Uppermost Jurassic-Eocene pelagic carbonate deposits of the Lattimusa, Hybla and Amerillo Fms. (tab. 3, respectively LTM, HYB and AMM on the map), follow upwards.

A prominent thick massive, tabular and/or lenticularshaped Upper Cretaceous carbonate megabreccia is interlayered into the Amerillo Fm.

The Amerillo Fm, in its turn, is unconformably covered by the Lower-to-Middle Miocene «Corleone calcarenites" and topwards the San Cipirrello marls.

Three main sections (fig. 9a), having different tectonosedimentary patterns, are described to illustrate the variable stratigraphic settings of the Rocca Busambra ridge.

\section{a) Piano Pilato section}

It is located at the westernmost side of Rocca Busambra (fig. 9b). The succession shows a Jurassic «condensed pelagic» facies association (Buccheri Fm), unconformably followed by both the Upper Cretaceous pelagic limestones (Amerillo Fm) and by the Lower Miocene reworked pelagic deposits («Corleone calcarenites»). This sequence rests unconformably above the sub-horizontal beds of the Inici Fm peritidal limestones.

Synsedimentary tectonics originated several, southdipping, largely subvertical $\left(60-80^{\circ}\right.$ steep) WNW-ESEoriented paleofaults displacing the Inici Fm deposits (fig. 6 on the frame of the map). The fault planes are sealed by Upper Jurassic, reworked, pelagic deposits (upper member of the Buccheri Fm) that lie with a buttress unconformity against the hanging-wall scarp of the fault plane. The western side of Piano Pilato (Pizzo Nicolosi) shows several WNW-ESE faults that downthrow the Jurassic carbonates, giving rise to a horst and graben setting (Pizzo Nicolosi and Rocca Ramusa graben structures, fig. 3 on the frame of the map); the morphotectonic depressions are filled by a 40 m-thick package of Upper Cretaceous pelagic deposits of the Amerillo Fm. The latter directly onlaps the Jurassic floor of the depressions; in the meantime they crop out, with buttress unconformity, against the subvertical walls (fig. 4 on the frame of the map).

\section{b) Rocca Busambra-peak section}

Located in the central sector of the ridge (fig. 9b), the Rocca Busambra-peak shows the carbonate megabreccias that either rest unconformably over the Jurassic condensed deposits of the Buccheri Fm or abruptly onlap the peritidal limestones of the Lower Jurassic Inici Fm (fig. 5 on the frame of the map). At places, the former fill up shallow, channelled gullies. The mapped synsedimentary tectonic structures are subvertical ENE-WSW normal faults (with a few to several metres of downthrow) that dissect the Inici Fm peritidal limestones and the Jurassic condensed Buccheri Fm deposits (fig. 5 on the frame of the map).

\section{c) Pizzo Marabito section}

Located along the easternmost side of the ridge (fig. 9b), the rock succession deeply differs from those 
previously described. The Upper Triassic reef of the Marabito limestones is unconformably overlain, with buttress unconformity, by both the Buccheri and Lattimusa Fms (fig. 8 on the frame of the map). Synsedimentary tectonic features in the Upper Triassic reef limestones are fissures, neptunian dykes and in situ breccias. ENE-WSW trending pre-Upper Jurassic subvertical fault planes are also present (fig. 8 on the frame of the map).

\section{MIOCENE FOREDEEP (WEDGE-TOP BASIN) DEPOSITS}

Upper Miocene deltaic conglomerate, sandstone and clay, pertaining to the Castellana Sicula and Terravecchia Fms. (tab. 4), are mapped in the southwestern area.

The Castellana Sicula Fm (SIC on the map), is a clayey sequence with quartz sandstone intercalations, a few metres to $150 \mathrm{~m}$-thick. It unconformably overlies the San Cipirello marls at Vallone del Poggio (west of the town of Corleone), Trentasalme and Bicchinello areas (immediately to the south and south-west of Pizzo Nicolosi), or the numidian flysch at Contrada Pirrello and Casale (south of Rocca Busambra) and the Sicilidi deposits at Contrada Bifarera (northern edge of the map). The poorly and badly-preserved fossil content dates these deposits as Late Serravallian-Early Tortonian.

The Terravecchia Fm ( $\mathrm{TRV}_{1}$ and $\mathrm{TRV}_{2}$ members), is mapped at Cozzo Riddocco and Vallone del Poggio (southwest of Corleone). The basal member consists of calcareous and siliceous graded conglomerates; these display lenticular and pinch-out geometries and thickness variability from a few metres to up to $20 \mathrm{~m}$. The conglomerate elements, mostly consisting of glauconitic "Corleone calcarenites», suggest that the source areas of the clastic material are those of the substrate that they overlie. Differently, the same deposits outcropping at Contrada Bifarera (north of Rocca Busambra, immediately off the map) consist of siliceous and quartzarenitic elements, suggesting an overall cannibalization of the quartz-sandstones of the numidian flysch.

The overlying member displays cross-laminated sandstones, up to $30 \mathrm{~m}$-thick, laterally and upwards passing to siltitic and grey clays, pertaining to the pelitic member (outcropping just outside the edge of the map). The fossil content of the clayey lithologies indicates their Late TortonianEarly Messinian age (Di SteFAnO \& CATALANO, 1978). The basal boundary of the Terravecchia Fm is an erosional unconformity above the older rock units; it is well shown at the Vallone del Poggio area, where the formation overlies sandstones and clays of the Castellana Sicula Fm.

\section{QUATERNARY DEPOSITS}

Quaternary-to-Recent deposits, developed in the frame of the morphogenetic evolution of the area, are mapped in detail with the aim of supplying basic infor-

Fig. 7 - Proposed type section of the Corleone calcarenites at Rocca dei Maschi (town of Corleone). The columnar section displays the sedimentological and lithological characters of the several lithological intervals and facies associations distinguished, and the cyclic arrangement of the succession (T-R sequence cycles and parasequences). In the picture below (Rocca dei Maschi natural section) are overprinted the lithological intervals $(a$ to $d$ ), the T-R cycles (R1, R2) and the parasequence cycles (white arrows); The time interval of the uppermost cycle is based on the occurrence of the markers of the Praeorbulina glomerosa s.l. biozone.
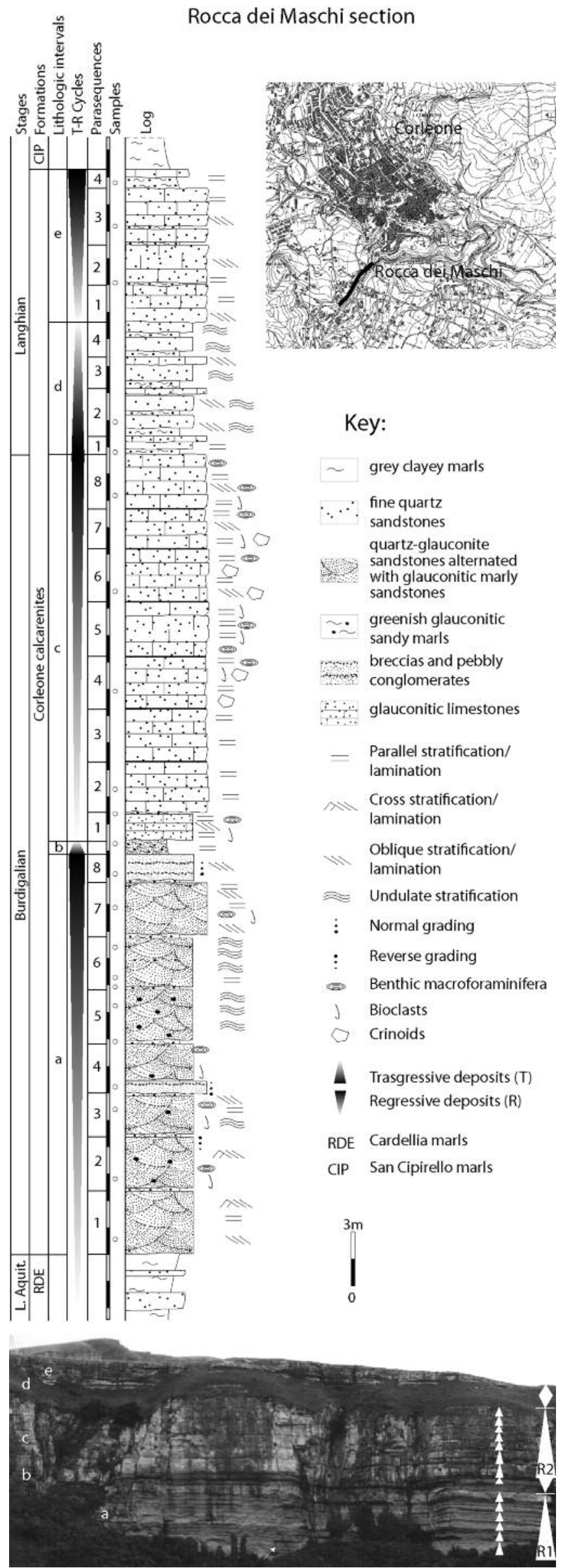
TABLE 3

Lithostratigraphic characters of the Triassic-Miocene formations of the Trapanese Rocca Busambra succession.

\begin{tabular}{|c|c|c|c|c|c|c|}
\hline \multicolumn{2}{|c|}{ Fms } & Main lithology & Lower boundary & & Fossil content & Age \\
\hline \multicolumn{2}{|c|}{$\begin{array}{l}\text { San Cipirello } \\
\text { marls (CIP) }\end{array}$} & $\begin{array}{l}\text { brown and dark clayey marls, } \\
\text { locally with glauconite }\end{array}$ & $\begin{array}{l}\text { conformable with } \\
\text { CCR }\end{array}$ & 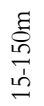 & $\begin{array}{l}\text { planktonic forams (MMi 5-MMi } 9 \text { and MMi } 11 \\
\text { biozones) calcareous nannofossils (MNN5b-MNN } \\
7 \mathrm{~b} \text { and Minylitha convallis biozones) }\end{array}$ & $\begin{array}{l}\text { Upper Langhian- } \\
\text { Lower Tortonian }\end{array}$ \\
\hline \multicolumn{2}{|c|}{$\begin{array}{l}\text { Corleone } \\
\text { calcarenites } \\
\text { (CCR) }\end{array}$} & $\begin{array}{l}\text { yellow-green glauconitic } \\
\text { globigerinid-bearing packstone- } \\
\text { grainstone }\end{array}$ & $\begin{array}{l}\text { buttress unconformity } \\
\text { with INI }\end{array}$ & క్లి & $\begin{array}{l}\text { planktonic forams (Globigerinoides trilobus, Praeorbulina } \\
\text { glomerosa } \text { s.l. biozones) }\end{array}$ & $\begin{array}{l}\text { Burdigalian- } \\
\text { Langhian }\end{array}$ \\
\hline \multicolumn{2}{|c|}{$\begin{array}{l}\text { Amerillo Fm. } \\
\text { (AMM) }\end{array}$} & $\begin{array}{l}\text { white and red planktonic } \\
\text { foraminifers-bearing wackestone } \\
\text { and calcareous megabreccias }\end{array}$ & $\begin{array}{l}\text { paraconformable on } \\
\text { HYB, buttress } \\
\text { unconformity with } \\
\text { BCH and INI }\end{array}$ & 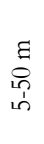 & $\begin{array}{l}\text { plankton forams (Rotalipora reicheli, Rotalipora } \\
\text { cushmani, Globotruncana ventricosa, Turborotalia } \\
\text { cerroazulensi s.l. biozones), calcareous nannofossils } \\
\text { (CC10 biozone) }\end{array}$ & $\begin{array}{l}\text { Cenomanian- } \\
\text { Maastrichtian and } \\
\text { Upper Eocene }\end{array}$ \\
\hline \multicolumn{2}{|c|}{$\begin{array}{l}\text { Hybla Fm. } \\
\text { (HYB) }\end{array}$} & $\begin{array}{l}\text { marls and cherty limestones; bio- } \\
\text { intraclastic (Aptychus and mollusc } \\
\text { fragments) floatstone }\end{array}$ & transitional on LTM & 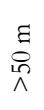 & $\begin{array}{l}\text { planktonic forams (Globigerinelloides algeriana, } \\
\text { Biticinella breggiensis), calcareous nannofossils (CC7-8 } \\
\text { biozones) }\end{array}$ & Aptian-Albian \\
\hline \multicolumn{2}{|c|}{$\begin{array}{l}\text { Lattimusa } \\
\text { (LTM) }\end{array}$} & $\begin{array}{l}\text { pink to white thin bedded cherty } \\
\text { mudstone, locally intraformational } \\
\text { pebbly mudstone and } \\
\text { resedimented bioclastic breccias }\end{array}$ & $\begin{array}{l}\text { Transitional on } \mathrm{BCH}_{3} \text {; } \\
\text { onlap and buttress } \\
\text { unconformity with } \\
\text { INI and ITO }\end{array}$ & $\stackrel{\stackrel{E}{n}}{\omega}$ & $\begin{array}{l}\text { calcareous nannoplankton (Nannoconus steinmanni), } \\
\text { radiolarians, belemnites, ammonites and } \\
\text { calpionellids (Calpionella, Calpionellopsis and } \\
\text { Calpionellites biozones) }\end{array}$ & $\begin{array}{l}\text { Upper Tithonian- } \\
\text { Neocomian }\end{array}$ \\
\hline \multirow{2}{*}{ 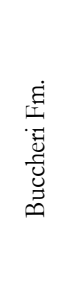 } & 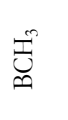 & $\begin{array}{l}\text { tabular and massive red to grey } \\
\text { pelagic crinoids-bearing } \\
\text { grainstone/packstone }\end{array}$ & $\begin{array}{l}\text { downlap or buttress } \\
\text { unconformity with the } \\
\mathrm{BCH}_{1}, \text { INI, ITO }\end{array}$ & 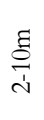 & $\begin{array}{l}\text { Saccocoma sp., benthic forams (Protopeneroplis } \\
\text { striata), Globochaete sp., Aptychus sp., } \\
\text { brachiopods, belemnites and ammonites }\end{array}$ & $\begin{array}{l}\text { Upper } \\
\text { Kimmeridgian- } \\
\text { Lower Tithonian }\end{array}$ \\
\hline & $\overline{U_{n}}$ & $\begin{array}{l}\text { reddish, brown to grey bioclastic } \\
\text { wackestone/packstone with dark } \\
\text { dm-sized Fe-Mn nodules, laminitic } \\
\text { stromatolites }\end{array}$ & $\begin{array}{l}\text { onlap with RND and } \\
\text { with the blackish Fe- } \\
\text { Mn crust capping the } \\
\text { Inici Fm. }\end{array}$ & ڤ్̃ี & $\begin{array}{l}\text { ammonites ( } S \text {. bumpresianum, G. garantiana, } P \text {. } \\
\text { parkinsoni, R. anceps biozones), radiolarians, thin- } \\
\text { shelled pelagic bivalves (Bositra buchi), } \\
\text { protoglobigerinids }\end{array}$ & $\begin{array}{l}\text { Bajocian-Lower } \\
\text { Kimmeridgian }\end{array}$ \\
\hline \multicolumn{2}{|c|}{$\begin{array}{l}\text { Crinoidal } \\
\text { limestones } \\
\text { (RND) }\end{array}$} & $\begin{array}{l}\text { Red to white massive grainstone } \\
\text { packstone, encrusted by Fe-Mn } \\
\text { oxides }\end{array}$ & onlap with INI & $\begin{array}{l}\text { E् } \\
\stackrel{0}{0} \\
\stackrel{0}{0}\end{array}$ & $\begin{array}{l}\text { Crinoid ossicles and plates (Pentacrinus sp.), benthic } \\
\text { foraminifera and ammonites }\end{array}$ & Toarcian \\
\hline \multicolumn{2}{|c|}{$\begin{array}{l}\text { Inici Fm. } \\
\text { (INI) }\end{array}$} & $\begin{array}{l}\text { algae and mollusc-bearing } \\
\text { wackestone-packstone, } \\
\text { stromatolithic and loferitic } \\
\text { packstone, oolitic and bioclastic } \\
\text { packstone/grainstone }\end{array}$ & $\begin{array}{l}\text { not outcropping. In } \\
\text { adjacent areas is } \\
\text { paraconformable on } \\
\text { Sciacca Fm. }\end{array}$ & छ̊ & $\begin{array}{l}\text { gastropods, brachiopods, ammonites (Arietites } \\
\text { bucklandi, Echioceras raricostatum), calcareous algae } \\
\text { (Cayeuxia sp., Thaumatoporella parvovesiculifera, } \\
\text { Paleodasycladus mediterranu), benthic foraminifera } \\
\text { (Involutina liassica) }\end{array}$ & $\begin{array}{l}\text { Hettangian- } \\
\text { Sinemurian }\end{array}$ \\
\hline \multicolumn{2}{|c|}{$\begin{array}{l}\text { Marabito } \\
\text { limestones } \\
\text { (ITO) }\end{array}$} & $\begin{array}{l}\text { dolomitized sponge-bearing } \\
\text { boundstone. It becomes a clast- } \\
\text { supported in situ breccias }\end{array}$ & $\begin{array}{l}\text { not outcropping. A } \\
\text { lateral transition with } \\
\text { Sciacca Fm. is inferred }\end{array}$ & క్̊ & $\begin{array}{l}\text { Calcareous sponges (Follicatena irregularis, Panormida } \\
\text { sp., Cheilosporites tirolensis) associated with rare corals } \\
\text { and calcareous algae }\end{array}$ & Norian-Rhaethian \\
\hline
\end{tabular}

TABLE 4

Lithostratigraphic characters of the Miocene syntectonic deposits.

\begin{tabular}{|c|c|c|c|c|c|c|}
\hline \multicolumn{2}{|c|}{ Fms } & \multicolumn{2}{|l|}{ Main lithology } & \multicolumn{2}{|l|}{ Environ } & Age \\
\hline 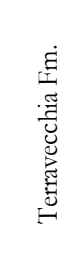 & $\underset{\sim}{\not N}$ & $\begin{array}{l}\text { Yellowish badly cemented quartz sandstones in thick beds, } \\
\text { with planar and crossed lamination and bioturbation and thin } \\
\text { conglomerate intercalations } \\
\text { Large-size (decimetric) grey and withish calcareous and } \\
\text { siliceous conglomerates, frequently embriciated and graded; } \\
\text { the elements deriving, mostly, from dismantling of the CCR }\end{array}$ & 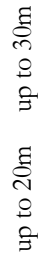 & 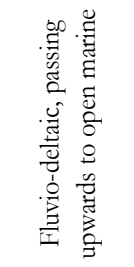 & $\begin{array}{l}\text { Planktonic forams (MMI5- MMI } 11 \\
\text { biozones); calcareous nannofossils (MNN } \\
6 \mathrm{a}, \mathrm{MNN} 7 \mathrm{a} \text { and Minilytha convallis (pars), } \\
\text { Reticulofenestra rotaria biozones). The fossil } \\
\text { conten has been found in the upper pelitic } \\
\text { member, not outcropping in the map }\end{array}$ & 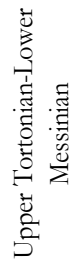 \\
\hline $\begin{array}{l}\text { Castell } \\
\text { Sicula } \\
\text { (SIC) }\end{array}$ & & $\begin{array}{l}\text { Grey, white-yellowish clays and sandy clays with poorly and } \\
\text { bad-preserved benthic foraminifera (Ammonia inflata, } \\
\text { Elphidium spp.) with, locally, thick intercalations of quartzitic- } \\
\text { micaceous sandstones }\end{array}$ & 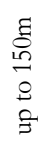 & $\begin{array}{l}\text { Open } \\
\text { platform- } \\
\text { to-slope }\end{array}$ & $\begin{array}{l}\text { Planktonic forams (Neogloboquadrina } \\
\text { praeatlantica, Neogloboquadrina acostaensis } \\
\text { biozones) }\end{array}$ & 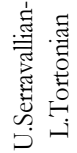 \\
\hline
\end{tabular}



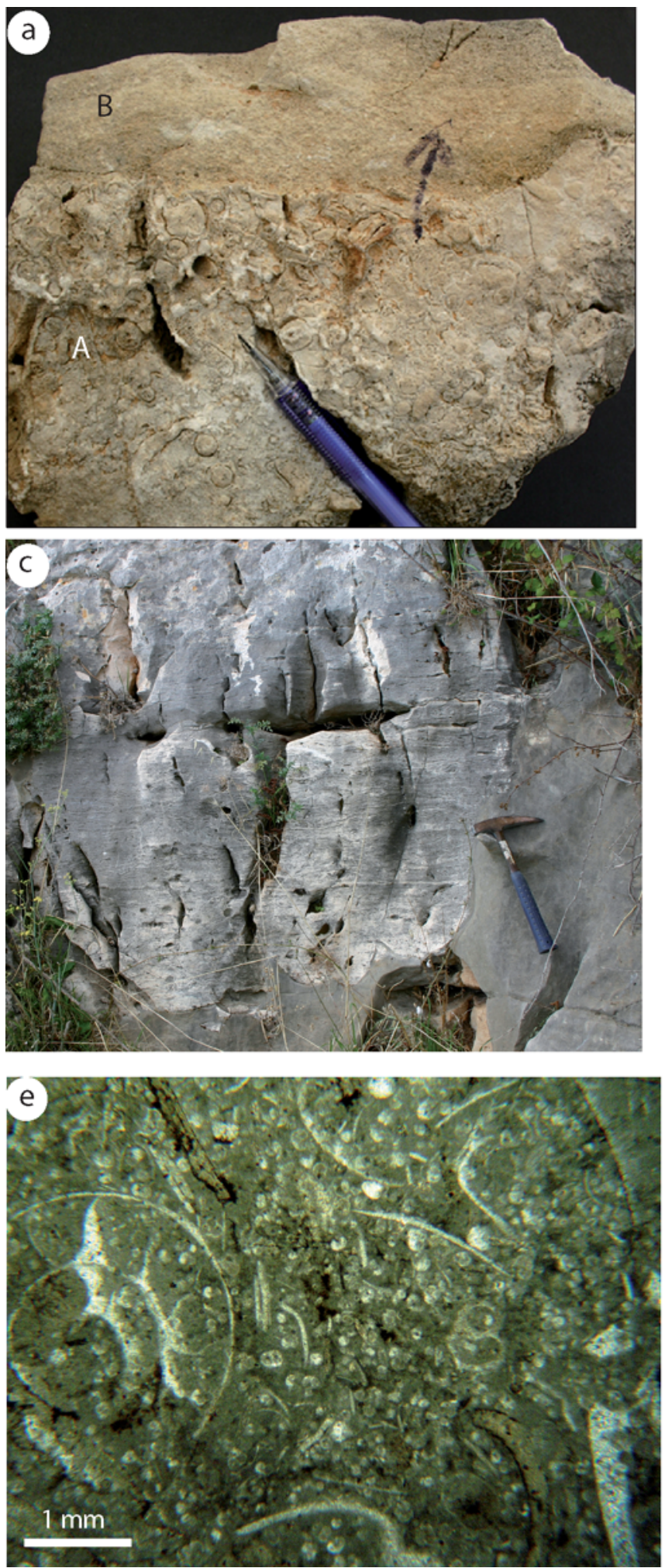
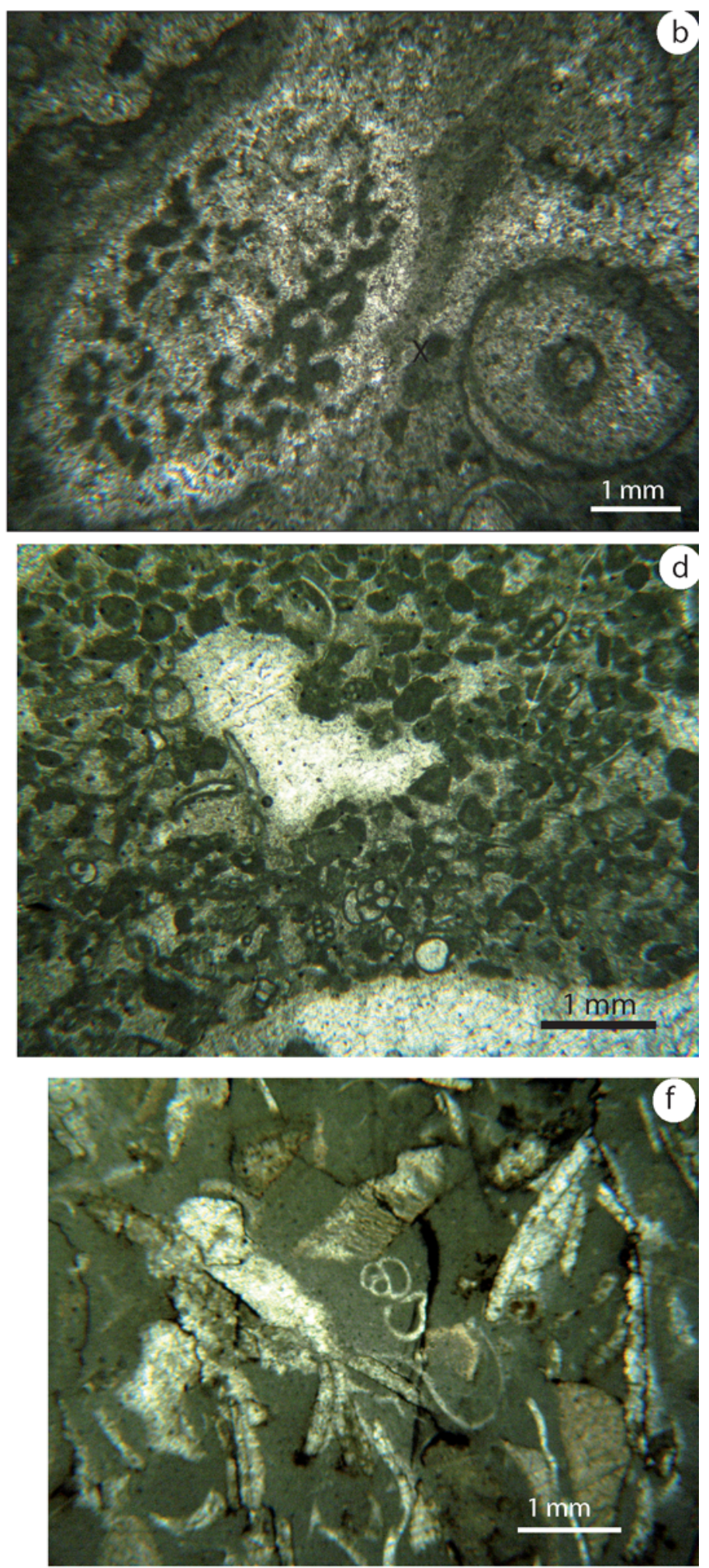

Fig. 8 - Characteristic lithofacies and microfacies of the Upper Triassic-Lower Jurassic carbonate shallow-water deposits (Marabito limestones and Inici Fm) and the Jurassic «Rosso Ammonitico» deposits (Buccheri Fm) outcropping along the Rocca Busambra ridge: $a$ ) dolomitized Upper Triassic sponge-bearing boundstone (A) followed upwards by oolitic grainstone (B), Pizzo Marabito. The boundary between the two lithofacies is an erosional surface; $b$ ) the same facies as above, showing cement (X) filling the space in between sponge elements; $c$ ) stromatolite lithofacies of the Lower Jurassic peritidal limestones (Inici Fm), intersected by subvertical neptunian dyke (hammer); $d$ ) oolitic and bioclastic grainstone with benthic foraminifers of the Inici Fm; e) wackestone with ammonites, radiolarians, Aptychus and thin-shelled fragments of the Bositra limestones (lower mb of the Buccheri Fm); $f$ ) packstone with thick-shelled molluscs, echinoid fragments, benthic foraminifers (Saccocoma limestones, upper mb of the Buccheri Fm). 


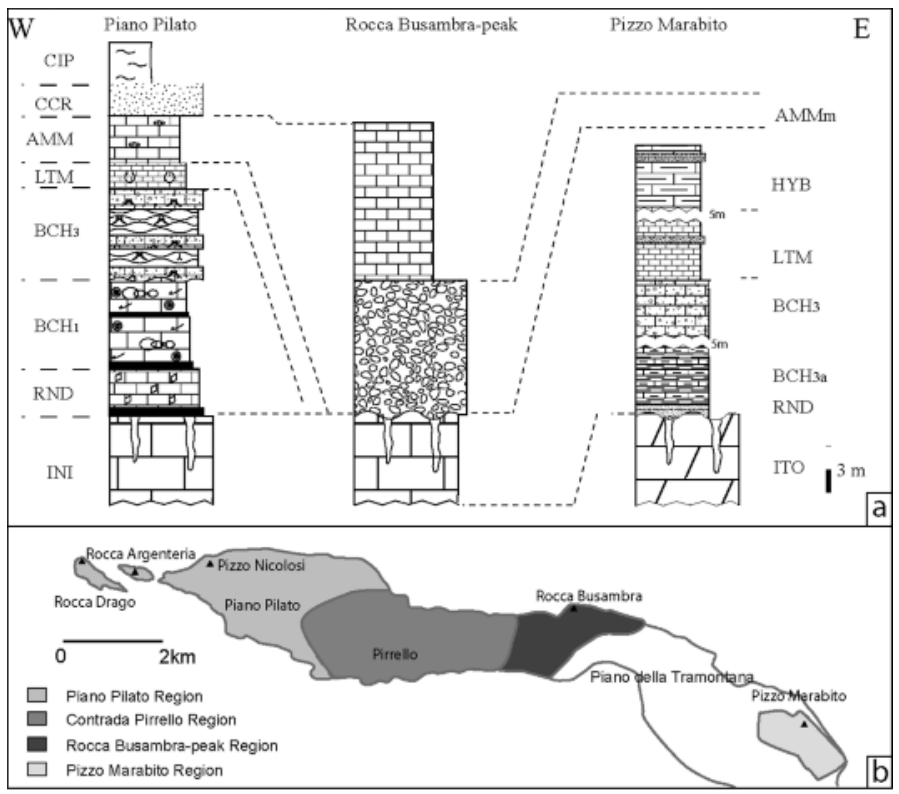

Fig. 9 - a) Stratigraphic sections measured and sampled along the Rocca Busambra ridge. In $b$ ) detail of the different regions distinguished.

mation for territorial planning purposes. The rocks are grouped in synthems (UBSU, sensu SALVADOR, 1994), as recently described by Di MAGGIO et alii (2009).

Continental and alluvial deposits, originated from the last postglacial phase, are grouped in the Capo Plaia synthem.

The synthem encompasses: a) scree and debris flow outcropping along the foot of the carbonate massifs (AFLa on the map); b) eluvial products and colluvial deposits, consisting of heterometric clasts, welded in a clayey matrix (AFLb on the map); these deposits are due to in situ alterations of the substrate and to geomorphological side processes; $c$ ) alluvial deposits, consisting of clays, sands and pebbly grains, outcropping along the rivers or forming terrace deposits (AFLc on the map); d) active and quiescent landslides (AFLd on the map), related to rotational and deep-seated gravitational processes, are widely diffused in the study region.

\section{TECTONICS}

A structural map (fig. 9 on the frame of the map) and some geological cross-sections (figs. 10, 14 and geological cross-section AA" on the frame of the map) display the tectonic setting of the study area and the geometrical relationships among the mapped rock units. The structural relationships among the tectonic units are recognized also with the help of the published subsurface seismic data. The tectonic edifice includes (from the top): Middle-Upper Miocene syntectonic deposits; Sicilide nappe, that overthrusts the numidian flysch tectonic unit at Cozzo Arcuri (northern edge of the map). The numidian flysch tectonic wedge overthrusts the Sicanian Corleone-Barracù tectonic unit. These units, in turn, tectonically rest above the Trapanese-derived carbonate plat- form Busambra tectonic unit.

When carefully investigated, each one of the main tectonic units displays different structural elements and internal deformations.
1) The syntectonic deposits (Castellana Sicula and Terravecchia Fms), mostly outcropping in the southwestern corner of the map, are deformed by successive folds and, mainly, by NE-SW to NW-SE oriented strike slip and normal faults. The geological sections across the area (fig 10a and geological cross-section AA" on the frame of the map) show how the deposits, mapped north of the Rocca Busambra ridge, unconformably seal the Sicilide and numidian flysch rock bodies; while, the deposits mapped at Vallone del Poggio-Cozzo Riddocco (south of Rocca Busambra) unconformably lie above the Middle Miocene Sicanian deposits.

2) The large, thick numidian flysch tectonic unit (from now on named the NFU unit), overthrusts, along a nearly flat surface, the Miocene San Cipirello marls and «Corleone calcarenites» of the Sicanian Corleone-Barracù tectonic unit, as shown in the Pirrello and Lavanche regions (to the south of Rocca Busambra), at Cozzo Zuccarone, at Tagliavia, Bifarera (original tectonic window) and at Scalilli (north-western corner of the map). At Casale (immediately south of Piano Pilato), Puntale l'Ape and at Cozzo Tondo (northern side of the Rocca Busambra-peak) the unit, tectonically, rests above the Upper Triassic Mufara Fm folded beds (geological cross-section AA" on the frame of the map and fig. 10d). In the Bosco della Ficuzza region, the NFU unit displays large (decametric wavelength) NW-SE-oriented folds, back-verging NEwards (fig. 10b). NE-SW-oriented strike-slip faults, related to a southwest-verging fold-system, dissect the quartz-sandstone numidian flysch intercalations at Cozzo Donna Giacoma and at Bosco della Ficuzza.

3) The Corleone-Barracù tectonic unit (from now on named the CBU unit) is mapped: $a$ ) at Contrada Bifarera (northwestern corner of the map), along the Cozzo Zuccarone structure and around the town of Corleone, where it is represented by Oligo-Miocene carbonate-clastic rocks; b) at Piano della Tramontana-Pizzo di Casa and Monte Barracù, where the unit is made of thick, and strongly deformed, Cretaceous-to-Lower Oligocene pelagic limestones and $c$ ) along the steep scarps of the Rocca Busambra ridge, where only scattered patches of the Mufara Fm, tectonically overlying the Miocene San Cipirrello marls, are present.

At Contrada Bifarera the Sicanian rocks are thrust, along high-angle reverse faults, over the already emplaced numidian flysch tectonic unit (fig. 10a).

The main setting of the CBU unit, characterized by asymmetric folds, internal low-angle reverse faults and décollement surfaces, is outlined by two culminations:

i) the Cozzo Zuccarone is an E-W and WNW-ESE oriented antiform with narrow and asymmetric southverging folds (geological cross-section AA" on the frame of the map and fig. 10a); the structure is evidenced by the occurrence of the carbonate "Corleone calcarenites» layer, sandwiched by two marly clay levels (Cardellia marls and San Cipirrello marls). The antiform is also dissected by NW-SE right-handed strike-slip faults, oblique to the major fold hinges. Locally (Cozzo Spolentino), low angle thrust planes imbricate the Oligocene-Miocene clastic-carbonate sequence, showing splay geometries (fig. 10c). This tectonics confirm that the Oligo-Miocene clastic sequence appears wholly detached from the underlying Amerillo Fm substrate (figs. 10a-c).

ii) Piano della Tramontana is a W-E and WNW-ESE oriented antiform with hectometric wavelength (fig. 11). 

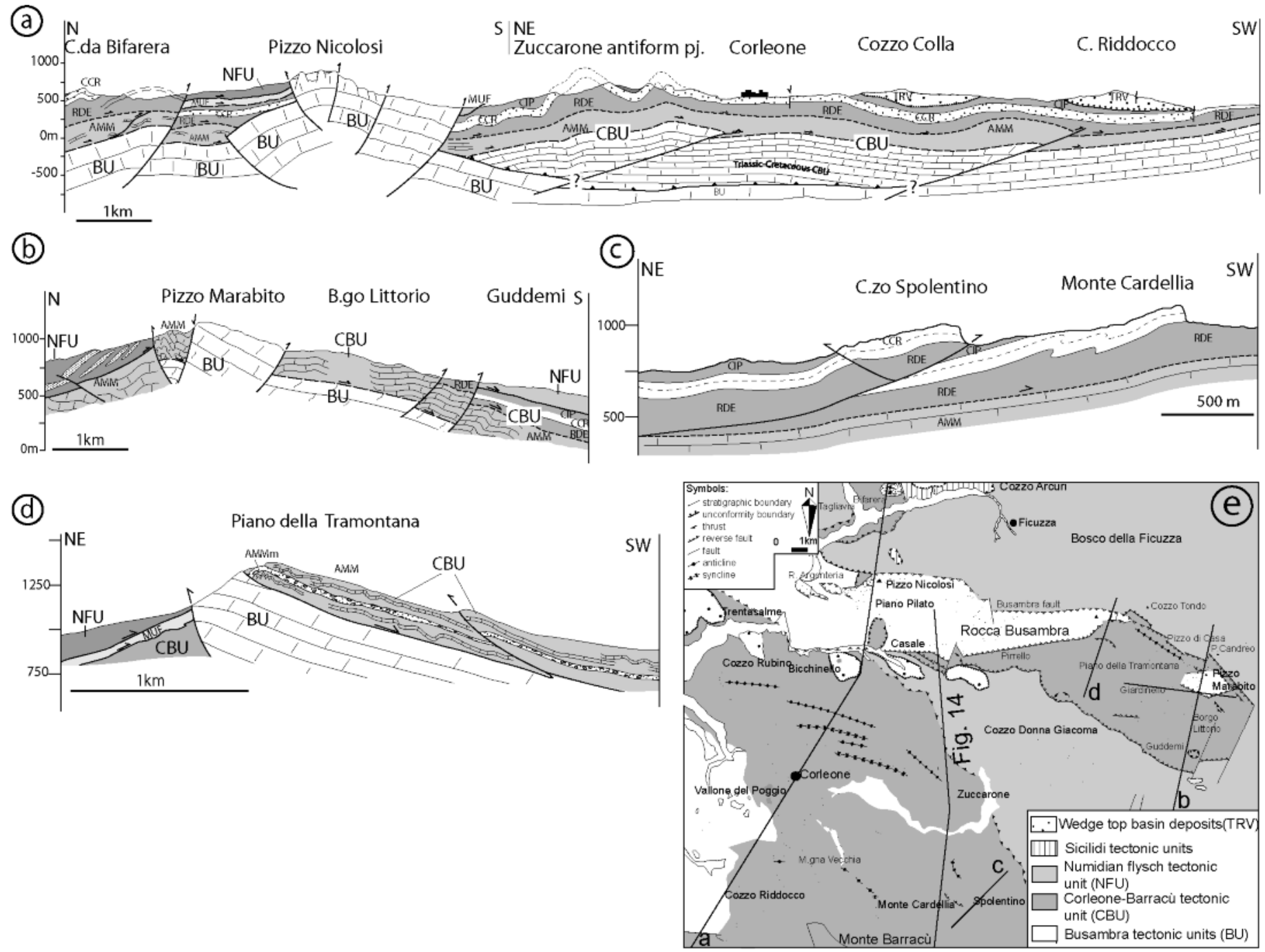

Fig. 10 - Tectonic relationships among the outcropping structural units in the study region. The Trapanese Busambra carbonate platform tectonic unit (BU) is the lowermost structural level of the tectonic edifice. This unit, in its turn, is overthrust, along low-angle tectonic surfaces, by the Sicanian Corleone-Barracù (CBU) and numidian flysch (NFU) tectonic units. The present-day structural setting is due to the deep-seated high-angle reverse faults with lateral component of movement. Traces of the $a, b, c, d$ and of fig. 14 geological cross-sections are located in the structural map (e).

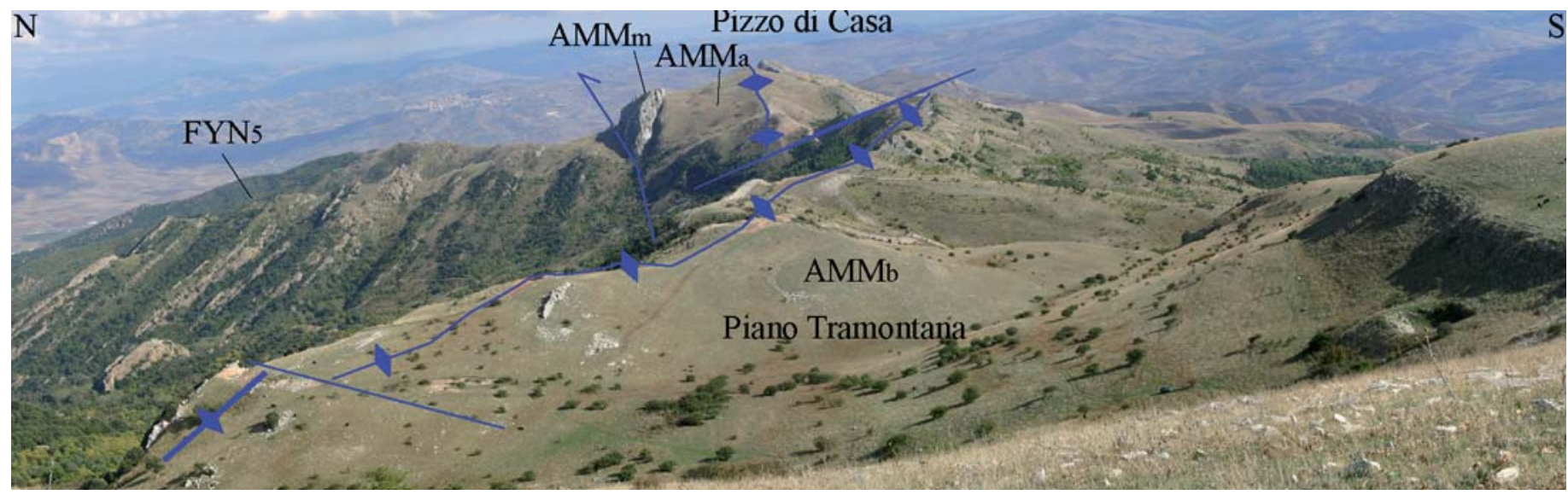

Fig. 11 - Piano della Tramontana antiform, eastern side of Rocca Busambra. It is possible to see the tectonic contact between the Pizzo di Casa Sicanian deposits (AMMm: calcareous megabreccias, AMMa red scaglia and AMMb white Scaglia of the Amerillo Fm) with the numidian flysch $($ Geraci Siculo mb, FYN 5 ). At Piano della Tramontana the ENE-WSW oriented anticline is displaced by NS faults. 


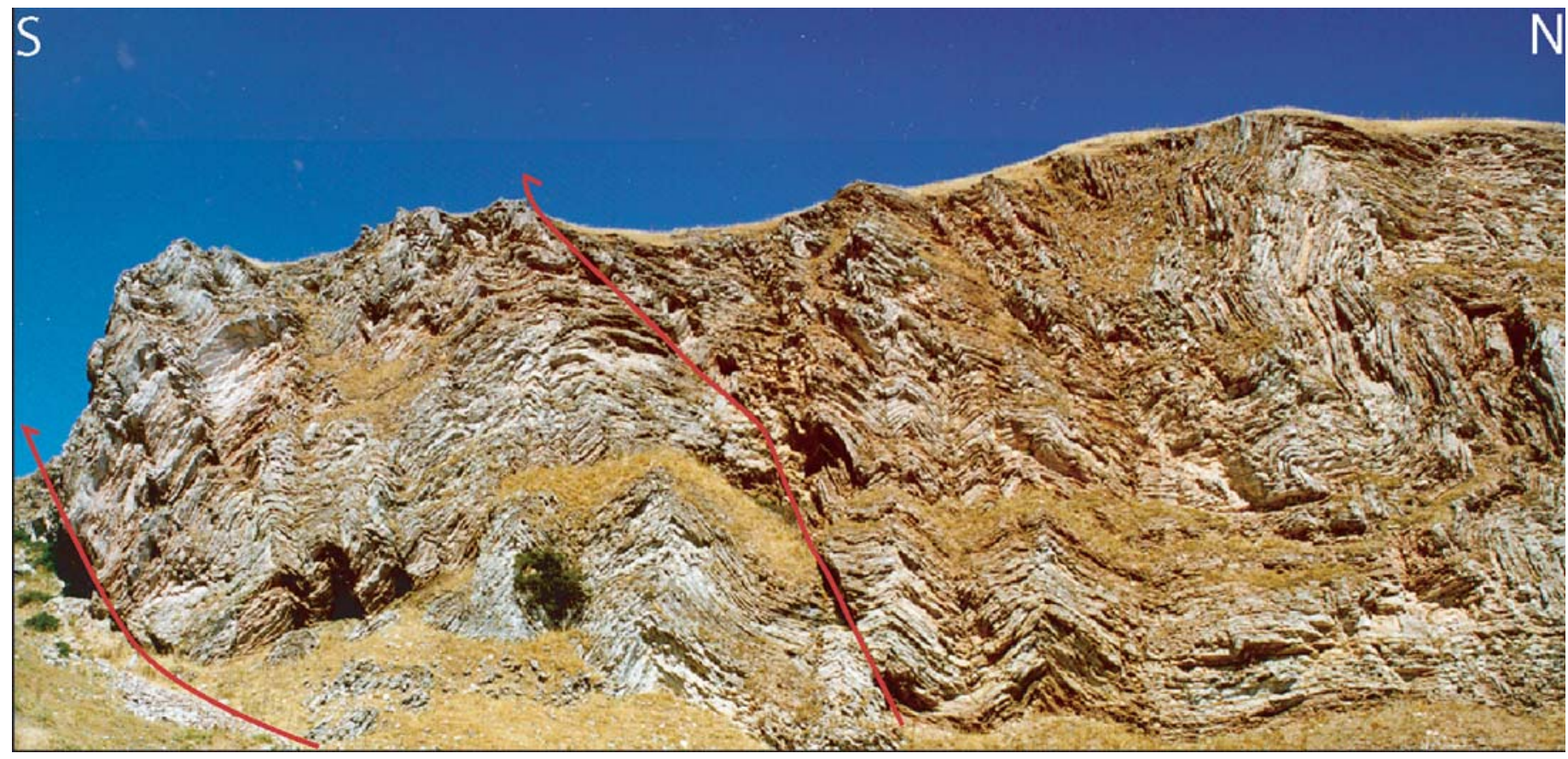

Fig. 12 - South-verging chevron folds and reverse faults in the pelagic Amerillo Fm at Pizzo di Casa (eastern side of Rocca Busambra ridge).

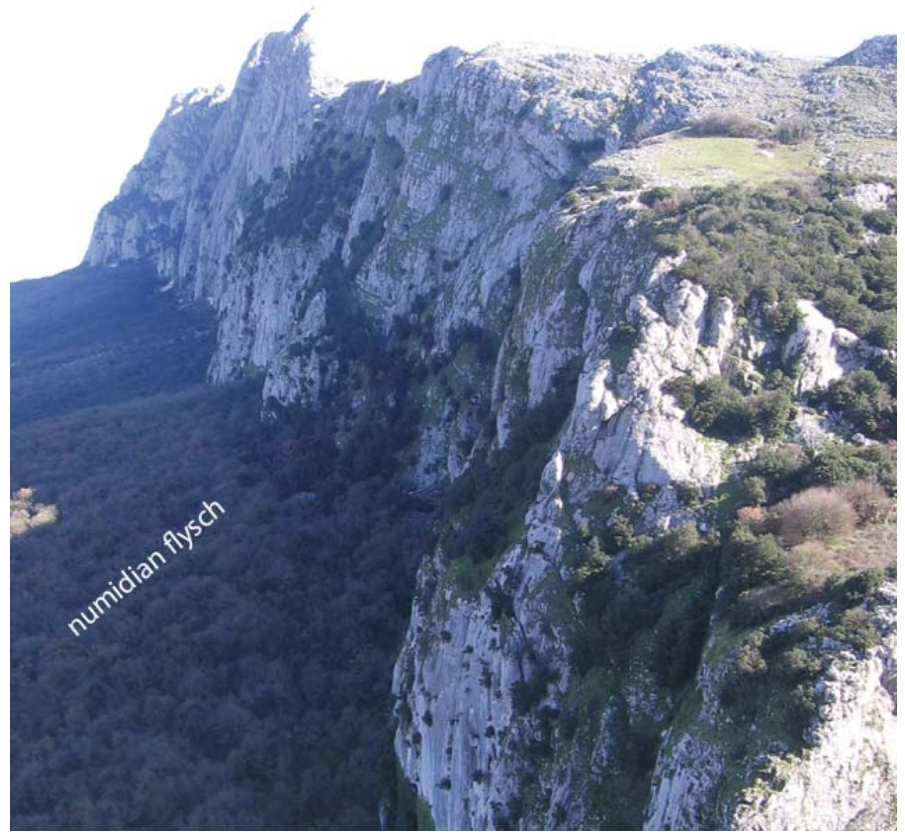

Fig. 13 - Morphostructural scarp of the Busambra high-angle reverse fault, along which the carbonate unit overthrusts the numidian flysch tectonic unit. Northern side of Rocca Busambra.

The core of the major anticline displays a south-verging narrow fold-system of chevron and box-fold type, further displaced by south-verging low-angle reverse faults (fig. 12). Disharmonic surfaces separate the more ductile upper Mesozoic-Paleogene strata from the lower Mesozoic deepwater limestones (mainly Scillato Fm). The antiform is bounded northwards by a transpressional high-angle back-thrust that downthrows the numidian flysch wedge with respect to the pelagic limestones (fig. 11). Westwards (near the Rocca Busambra-peak), the previously- mentioned Piano della Tramontana antiform overthrusts the Busambra tectonic unit, as evidenced by the periclinalic culmination of the folded Sicanian thin-bedded limestones (fig. 10d).

4) The Busambra tectonic unit (from now on named the BU unit) develops along the Pizzo Nicolosi-Pizzo Marabito ridge as an E-W to NW-SE trending large carbonate antiform. The structure is bounded northward and southward by E-W and WNW-ESE high-angle reverse faults, which separate the carbonate platform unit from the adjacent numidian flysch and Sicanian units (figs. 10a, b, d and fig. 6 on the frame of the map). Eastwards the unit disappears beneath the Sicanian Cretaceous-Lower Oligocene pelagic limestones outcropping at Piano della Tramontana. At Pizzo Marabito the carbonate structure plunges to the east disappearing beneath the numidian flysch unit.

The main tectonic lineaments mapped along the Busambra unit are:

- WNW-ESE and NW-SE syndepositional extensional-to-transtensional faults and fractures (CATALANO \& D'ARgENIO, 1982b; BASILONE et alii, 2010) dissecting the Mesozoic carbonates at different stratigraphic levels (figs. 4-8 on the frame of the map);

- large N-S and NNW-SSE oriented structures folding the Mesozoic limestones.

- E-W to NW-SE transpressional, high-angle fault, characterized by several hundreds of metres of downthrow, associated to vertical fault line scarps (Busambra fault, fig. 13). The south-dipping fault planes display kinematic indicators, suggesting dextral movements along the fault planes (CATALANO et alii, 2010a, b).

- WNW-ESE, W-E and WSW-ENE striking and southward-verging, high-angle thrust faults characterize the southern side of Rocca Busambra (fig. 10a and fig. 6 on the frame of the map);

- NS and NNE-SSW oblique faults with left-lateral component of motion (tear faults?), dipping to the $\mathrm{E}$ and 


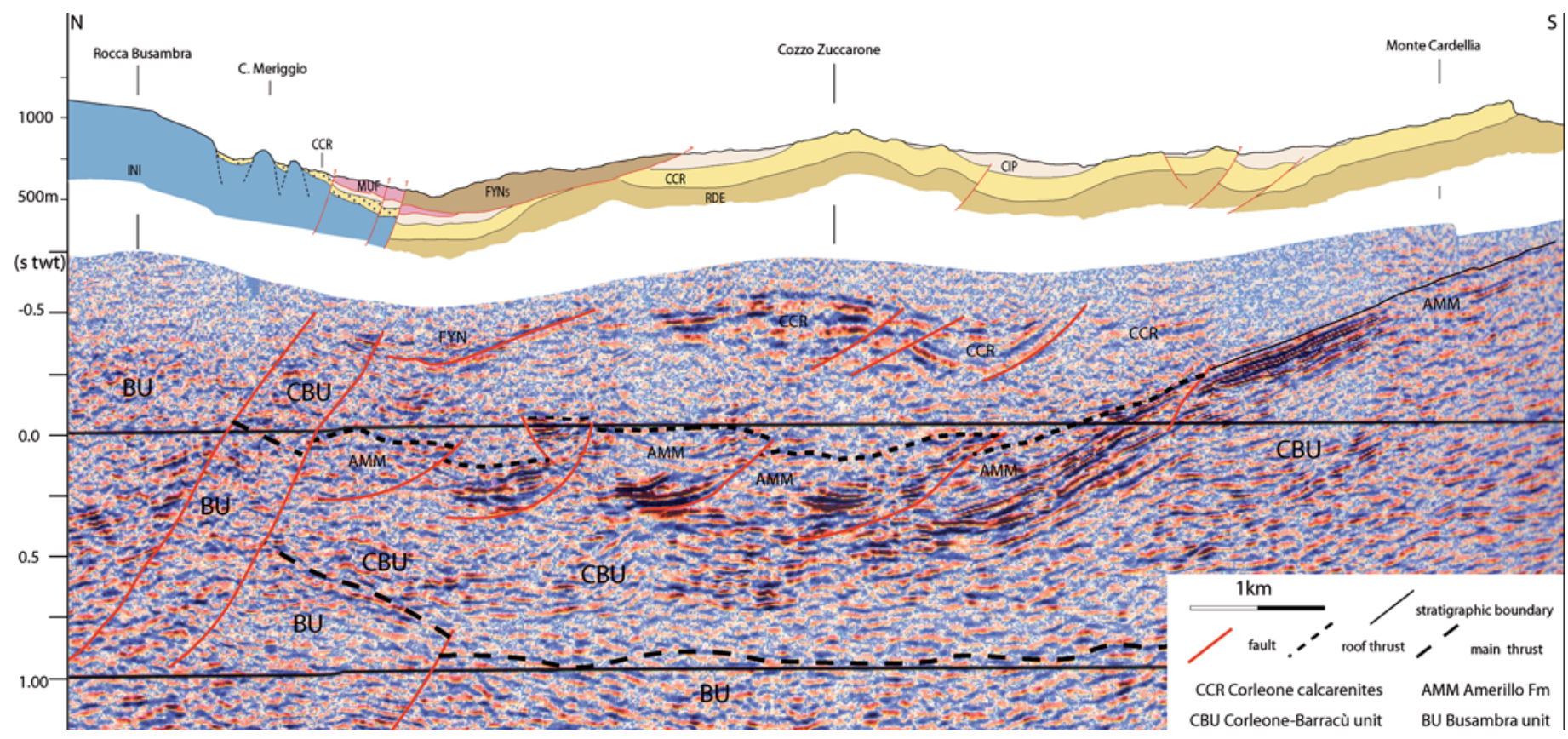

Fig. 14 - a) The seismic profile across the Rocca Busambra-Monte Cardellia area (see trace in fig. 10a) shows the structural relationships between the Trapanese carbonate platform Busambra unit (BU) and the deep-water Sicanian Corleone-Barracù unit (CBU); $b$ ) The geological section, crossing the same area, shows the surface interpretation of the topmost part of the seismic profile.

ESE, dissect the central and eastern sectors of the ridge. These faults are antithetic to the main dextral transpressional E-W system.

- SW dipping, NW-SE trending normal faults displace the ridge structure, mostly in its westernmost sector.

\section{DISCUSSIONS}

The recognized surface structural setting is consistent with the buried structure reconstructed in the study region (fig. 14) according to geological interpretations of the seismic profiles crossing the area.

Comparing these interpretations provides a better understanding of: 1) the structural setting and the backthrust structures of the Rocca Busambra, 2) its paleotectonic evolution, 3) the deformation style of the Sicanian units and 4) the relationships between the Upper Miocene wedge-top basins deposits and the deformed substrate.

1) The Busambra unit, as described in this paper, is the culmination of a larger anticline, bordered by two, main transpressive faults of a south-verging ramp structure (figs. 10a and 14 and geological cross-section AA" on the frame of the map). The E-W high-angle back-verging reverse fault (Busambra fault, figs. 10a and 13), which gradually flattens with depth (see seismic interpretations by Agate et alii, 1998a; Catalano et alii, 2000 and Albanese et alii, 2005), might be considered as a deepseated structures.

The resulting structural setting is different compared to the previous interpretations: MASCLE (1979) described the BU unit as a sedimentary klippen resedimented in the Miocene marls basin. CATALANO et alii (1978), Roure et alii (1990), LENTINI et alii (1994), MonACo et alii (2000) interpreted the carbonate platform Busambra tectonic unit as primarily overthrusting the Sicanian rock units. However, Agate et alii (1998a) and Catalano et alii (2000), described the Sicanian units as overthrusting the Trapanese Busambra unit, based on seismic profiles interpretation. The local setting of the Trapanese rock units above the Sicanian ones is a late effect of the structural «envelopment» (out of sequence) between the two rock units.

The previously-mentioned transpressional Busambra fault was described as a normal fault (RouRe et alii, 1990), or a deep strike-slip fault (MONACO et alii, 2000), or a deep-seated positive flower structure in the frame of the main strike-slip tectonics (NIGRO \& RENDA, 2001).

2) In the Rocca Busambra ridge the Mesozoic synsedimentary tectonics and the restored depositional setting suggest the occurrence of a stepped fault margin with condensed sequences (Piano Pilato), passing to a horst and graben system (Pizzo Nicolosi) and to slope areas (Pizzo Marabito). The latter are characterized by a scalloped upper slope passing to a base-of-slope environment (Rocca Busambra-peak).

To consider the Piano Pilato stepped margin as the slope margin of the Barracù Sicanian basin (as proposed by MARTIRE \& BertoK, 2002 and BertoK \& MartiRe, 2009) appears difficult due to the structural setting discussed above (the Sicanian units regionally overthrust the Trapanese carbonate platform rock units, see also BASILONE, 2009).

The Mesozoic faults are reactivated by the deepseated transpressional structures, as proved by meso- 
structural analyses carried out along the Rocca Busambra ridge (BASILONE et alii, 2010). The latter show how the faults involving the Mesozoic deposits display the same trend of the Late Tertiary reverse faults crossing the mapped area. Similar features are described in adjacent regions (e.g. Kumeta ridge, AvELlone et alii, 2010).

3) The S- and SW-wards vergent Sicanian CorleoneBarracù tectonic unit is, on the whole, thrust over the carbonate Busambra tectonic unit along a partly buried low-angle surface (figs. 10a and 14a). Based on the field observation and on the seismic profile interpretation (fig. 14), a duplex geometry of the tectonic unit is pointed out. The duplex tectonic style of the CBU is in agreement with similar features described in the eastern Sicanian Mountains (Vitale \& Giambrone, 1995; Vitale, 1996; CATALANO et alii, 1996).

The detachment surfaces, within the deep-water Sicanian succession, disconnect the more ductile upper Mesozoic-Paleogene strata from the lower Mesozoic deep-water limestones. As a consequence, uncoupled levels of the $\mathrm{CBU}$ unit overlie the main thrust surface above the BU unit (as it is possible to observe in the geological map, along the southern limb of the Rocca Busambra ridge and in fig. 10d).

The originally flat thrust surface and the local décollements are, at present-day, tilted and deformed according to the late deformation of the carbonate platform substrate.

In detail, both the Oligo-Miocene roof thrust and the Cretaceous-Eocene horses were later redeformed giving rise to the main E-W and WNW-ESE plicative structures such as the splay structures (Cozzo Spolentino, fig. 10c), and the associated fold systems (e.g. Cozzo Zuccarone antiform, fig. 14 and Piano della Tramontana antiform).

4) The Middle-Upper Miocene deposits (Castellana Sicula and Terravecchia Fms) are believed to be deposited in a wedge-top depozone (CATALANO \& D'ARGENIO, 1990; BUTLER \& GRASSO, 1993). The mapped outcrops overlie different substrata and are characterized by lithological differences (nature of the conglomerates). These features demonstrate that these deposits were formed in separated basins, originally faraway from each other and respect to the present-day location, with different source areas of the clastic materials.

\section{Timing of deformation}

The tectonic edifice in the study area is the result of several deformational events, from the Triassic to the Pleistocene. These have deformed the sedimentary successions that settled along the African continental margin paleogeographic zone. The timing of the deformation is constrained by the age of the foredeep basins and the first unconformable deposits.

\section{Preorogenic phase}

During the Mesozoic-Early Miocene continental margin phase, synsedimentary tectonics accompany depositions in carbonate platform-basin systems. It is clearly put in evidence by both the syntectonic deposition along the Trapanese carbonate platform Rocca Busambra succession and the sudden thickness variations of the outcropping Sicanian succession.

\section{Postcollisional phase}

This phase started with the continental margin deformation, following the latest Oligocene-Early Miocene counter-clockwise rotation of Corsica-Sardinia and its collision with the African margin. During the collision time two main tectonic events occur. The older documented deformation relates to the emplacement of the Sicilidi units above the Lower Miocene numidian flysch. The latter is, at present time, stacked above Lower Tortonian marls, representing the top of the Sicanian Units. There is a large consensus about the decoupling of the numidian flysch from its Imerese (or more internal) Meso-Cenozoic carbonate substrate. Both the Imerese units and the already detached numidian flysch units were emplaced above the Sicanian units after the Early Tortonian (figs. 1 and 2 on the frame of the map and MASCLE, 1979; CATALANO \& D'ARGENIO, 1978; Roure et alii, 1990). The deepsea rock bodies of the Sicanian domain appear thrust over the Lower Tortonian marls pertaining to the carbonate platform Trapanese Busambra succession. The latter appear involved in the deformation after the Sicanian units emplacement, as put in evidence by the already described local thrusting of the carbonate platform Busambra rock unit over the Sicanian Barracù tectonic unit. The Sicanian rock units appear redeformed, after the Miocene early tectonic event, as put in evidence by different orientation trends of the fold systems. This second plicative event caused the deformation of the MessinianLower Pliocene deposits, as shown in the surroundings of the study region, and took place in the Late Pliocene. More recent extensional tectonics (Early Quaternary times in western Sicily) are not clearly discernible in the area.

\section{CONCLUSIONS}

The geological map (1:37.500 scale) of the Rocca Busambra-Corleone region (central-western Sicily) is presented here, based on facies analysis, physical stratigraphy, biostratigraphy and structural analysis. The map, originally compiled at a 1:10,000 scale, represents a new approach to the geology of the region.

A detailed mapping and the stratigraphy illustrate the several outcropping lithostratigraphic units (more than 22 formations and members), some proposed type sections and the characters of the Piano della Tramontana (eastern side of the Rocca Busambra ridge) deposits as pertaining to the Sicanian succession.

The mesoscopic and large-scale structural analysis depicts a tectonic setting comparable with subsurface geometries (suggested by seismic data). The collected data restore a tectono-sedimentary evolution from Mesozoic extensional rifting-phase to Late Tertiary compressive belt deformation:

- extensional-to-transtensional Mesozoic-Lower Miocene tectonic pulses have punctuated the tectono-sedimentary evolution of the Rocca Busambra area;

- thin-skinned tectonics (shallow-seated structures) have developed with duplex and embricate fan geometry of the Sicanian deep-water carbonate and numidian flysch tectonic units. These units have progressively overthrust the Trapanese carbonate platform Busambra unit during the Late Miocene;

- deep-seated structures originated from a transpressional Pliocene tectonic event have deformed the Busambra unit at a depth. The late tectonics involve the already emplaced units (Sicilidi, numidian flysch and Sicanian units), that, in turn, are passively bent and redeformed. 


\section{ACKNOWLEDGMENTS}

This research was supported by PRIN 2006, CARG project and Miur (ex 60\%) 2006 grants (coord. Prof. R. Catalano). Two referees, Profs. C. Monaco and L. Ferranti, are acknowledged for their useful comments and suggestions, that improved the manuscript. Thanks are due to Profs. R. Sprovieri and E. Di Stefano for their biostratigraphic support and C. Di Maggio for his geomorphological comments. $\mathrm{S}$. Pierini helped in the graphics of the map.

\section{REFERENCES}

Agate M., Basilone L., Catalano R., Franchino A., Merlini S. \& Sulli A. (1998a) - Ipotesi sulla condizione strutturale della Rocca Busambra. In: R. CATAlano \& G. Lo Cicero (Eds.). La Sicilia un laboratorio naturale nel Mediterraneo. Strutture, Mari, Risorse e Rischi. Guida alle Escursioni del $79^{\circ}$ Congr. Nazionale della Soc. Geol. It. - La Sicilia Occidentale, 1, 71-78. Mondello (Palermo, Italia), 21-23 Settembre 1998.

Agate M., Basilone L., Catalano R., Franchino A., Merlini S. \& Sulli A. (1998b) - Deformazione interna delle Unità Sicane nell'area tra Corleone e Monte Colomba. In: R. CATALANO \& G. Lo CICERO (Eds.). La Sicilia, un laboratorio naturale nel Mediterraneo. Strutture, Mari, Risorse e Rischi. Guida alle Escursioni del $79^{\circ}$ Congr. Nazionale della Soc. Geol. It. - La Sicilia Occidentale, 1, 79-86, Mondello (Palermo, Italia), 21-23 Settembre 1998.

Agnesi V., Macaluso T., Monteleone S. \& Pipitone G. (1978) Espansioni laterali (lateral spreads) nella Sicilia Occidentale. Geol. Applicata e Idrogeologia, 13, 319-326.

Albanese C., Avellone G., Basilone L., Catalano R. \& Sulli A (2005) - Triangle zone and passive-roof duplexes in central western Sicily? new insight from seismic interpretation. Abs. vol., p. 51. Convegno FIST-Geoitalia 2005.

Alleman F., Catalano R., Farès F. \& Remane J. (1971) - Standard calpionellid zonation (Upper Tithonian-Valanginian) of the western Mediterranean province. Proc. II Plankt. Conference, 1337-1340. Roma.

Avellone G., Barchi M., Catalano R., Gasparo Morticelli M. \& Sulli A. (2010) - Interference between shallow and deep-seated structures in the Sicilian fold and thrust belt. Journal of the Geological Society, London, 167, 109-126.

BASILONE L. (2007) - Mesozoic tectono-sedimentary evolution of the Rocca Busambra (western Sicily). FIST - Geoitalia 2007, Sesto Forum Italiano di Scienze della Terra, 12-14 Settembre 2007, Rimini, Epitome, 2, 403.

BASILONE L. (2009) - Mesozoic tectono-sedimentary evolution of Rocca Busambra in western Sicily. Facies, 55 (1), 115-135.

Basilone L., Gasparo Morticelli M. \& Lena G. (2010) - Mesozoic tectonics and volcanism from Tethyan rifted continental margins in western Sicily. Sedimentary Geology, 226, 54-70.

Bernoulli D. \& Jenkyns H.C. (1974) - Alpine, Mediterranean and Central Atlantic Mesozoic facies in relation to the early evolution of the Tethys. Modern and ancient geosynclinal sedimentation. In: DotT R.H. \& SHAVER R.H. (Eds.). SEPM Spec. Publ., 19, 129-160.

BERTOK C. \& MARTIRE L. (2009) - Sedimentation, fracturing and sliding on a pelagic plateau margin: the Middle Jurassic to Lower Cretaceous succession of Rocca Busambra (Western Sicily, Italy). Sedimentology, 56 (4), 1016-1040.

Biolzi M. (1985) - The Oligocene/Miocene boundary in selected Atlantic, Mediterranean and Paratethyan sections based on biostratigraphic and stable isotope evidence. Mem. Sci. Geol., 37, 303-372.

ButleR R.W.H. \& GRASso M. (1993) - Tectonic controls on base-level variations and depositional sequences within thrust-top and foredeep basins: examples from the Neogene thrust belt of central Sicily. Basin Research, 5, 137-151.

CARON M. (1985) - Cretaceous planktic foraminifers. In: Bolli H.M., Saunders J.B. \& Perch-Nielsen K. (Eds.). Plankton Stratigraphy, Cambridge Univ. Preess, 1, 17-86.

CAtAlano R. \& D’ARgenio B. (1978) - An essay of palinspastic restoration across the western Sicily. Geol. Rom., 17, 145-159, Roma.

Catalano R. \& D'Argenio B. (1982a) - Schema geologico della Sicilia occidentale. In: R. CATALANo \& B. D'Argenio (Ed.). Guida alla geologia della Sicilia occidentale. Guide geologiche regionali, Mem. Soc. Geol. It., suppl. A 24, 9-41, Palermo.

CAtAlano R. \& D'ARgenio B. (1982b) - Infraliassic strike-slip tectonics in Sicily and Southern Apennines. Rend. Soc. Geol. It., 5, 5-10.

CAtalano R. \& D'Argenio B. (Eds.) (1990) - Hammering a Seismic Section. Field trip in Western Sicily, Guide Book. Dipartimento di Geologia e Geodesia, Univ. di Palermo, pp. 19-22. May 17-19, 1990.

Catalano R. \& Montanari L. (1979) - Geologia dei Monti di TrabiaTermini Imerese e dei Monti Sicani orientali (Fogli Bagheria e Termini Imerese, Sicilia centro-settentrionale). Rend. Soc. Nat. in Napoli, serie IV, 46, 1-27.

Catalano R., Avellone G., Basilone L. \& Sulli A. (2010a) - Note Illustrative della Carta Geologica d'Italia alla scala 1:50.000, foglio 607 «Corleone». Regione Siciliana - ISPRA, SystemCart, 190 pp.

Catalano R., Avellone G., Basilone L. \& Sulli A. (2010b) - Note Illustrative della Carta Geologica d'Italia alla scala 1:50.000, foglio 608 «Caccamo». Regione Siciliana - ISPRA, SystemCart, 224 pp.

Catalano R., D’Argenio B., Montanari L., Renda P., Abate B., Monteleone S., Macaluso T., Pipitone G., Di Stefano E., Lo Cicero G., Di Stefano P. \& Agnesi V. (1978) - Contributi alla conoscenza della struttura della Sicilia occidentale. Il profilo Palermo-Sciacca. Mem. Soc. Geol. It., 19, 485-493, Roma.

Catalano R., Di Stefano P., Sulli A. \& Vitale F.P. (1996) - Paleogeography and structure of the Central Mediterranean: Sicily and its offshore area. Tectonophysics, 260, 291-323.

Catalano R., Franchino A., Merlini S., Sulli A., Agate M. \& BASILONE L. (1998) - Materiali per la comprensione dell'Assetto Profondo della Sicilia Centro-Occidentale. In: Catalano R. \& Lo CICERO G. (Eds.). Guida alle escursioni, La Sicilia occidentale, $79^{\circ}$ Congresso della Società Geologica Italiana, Palermo, I, 175-185.

Catalano R., Franchino A., Merlini S. \& Sulli A. (2000) - Central western Sicily structural setting interpreted from seismic reflection profiles. Mem. Soc. Geol. It., 55, 5-16.

Catalano R., Sulli A., Abate B., Agate M., Avellone G. \& BASILONE L. (2004) - The crust in Western and Central Eastern Sicily. Field Trip Guide Book P45. 32 ${ }^{\circ}$ International Geological Congress, Firenze.

Channell J.E.T., Oldow J., Catalano R. \& D'Argenio B. (1990) Palaeomagnetically Determined Rotations in the Western Sicilian Fold and Thrust Belt. Tectonics, 9 (4), 641-660.

CHrist H.A. (1960) - Beitrage zur Stratigraphie and Palaontologie des Malm von West Sizilien. Schweiz. Palaeont. Abh., 77, 1-141, Basel.

Di Maggio C., Agate M., Contino A., Basilone L. \& Catalano R (2009) - I depositi quaternari nei fogli CARG della Sicilia nord occidentale: implicazioni climatiche, ambientali e tettoniche. Il Quaternario (Italian Journal of Quaternary Sciences), 22 (2), 347-366.

Di Stefano E. \& CATAlano R. (1978) - Biostratigraphy, palaeoecology and tectonosedimentary evolution of the preevaporitic deposits of the Ciminna basin (Sicilia). In: Catalano R., RugGIERI G. \& SPROVIERI R. (Ed.). Messinian Evaporites in the Mediterranean, Mem. Soc. Geol. It., 16, 95-110.

Di Stefano P. \& Mindszenty A. (2000) - Fe-Mn encrusted "Kamenitza» and associated features in the Jurassic of Monte Kumeta (Sicily): subaerial and/or submarine dissolution? Sedim. Geol., 132, 37-68.

Finetti I.R., Lentini F., Carbone S., Del Ben A., Di Stefano A., Forlin E., Guarnieri P., PiPAN M. \& Prizzon A. (2005) - Geological outline of Sicily and Litospheric Tectono-Dynamics of its Tyrrenian Margin from new CROP Seismic Data. Crop Project: Deep Seismic Exploration of the Central Mediterranean and Central Italy. Edited by I.R. FINETTI, 2005 Elsevier B.V.

Foresi L.M., Bonomo S., Caruso A., Di Stefano E., Salvatorini G. \& SPROVIERI R. (2001) - Calcareous plankton biostratigraphy of the Langhian-Serravallian Ras-Il Pellegrin section (Malta). In IACCARINO S. (Ed.). Integrated stratigraphy and paleoceanography of the Mediterranean Middle Miocene. Riv. Ital. Paleont. Strat., 108 (2), 195-211.

Fornaciari E., Di Stefano A., Rio D. \& Negri A. (1996) - Middle Miocene quantitative calcareous nannofossil biostratigraphy in the Mediterranean region. Micropaleontology, 42, 37-63.

Ghisetti F. \& VezzAni L. (1984) - Thin-skinned deformations of the Western Sicily thrust belt and relationships with crustal 
shortening: mesostructural data on the Kumeta-Alcantara fault zone and related structures. Boll. Soc. Geol. It., 103, 129-157.

GiUnta G. \& Liguori V. (1975) - Considerazioni sul significato ambientale e sul ruolo paleotettonico della Rocca Busambra (Sicilia). Boll. Soc. Nat. Napoli, 84, 45-49.

Gullo M. \& Vitale F.P. (1986) - The "Megabreccia event» in the Upper Cretaceous-Eocene "Scaglia» of Western Sicily. Rend. Soc. Geol. Ital., 9, 195-202.

IACCARINO S. (1985) - Mediterranean Miocene and Pliocene planktonic foraminifers. In: Bolli H.M., SAunders J.B. \& PERCH-NIElSEN K. (Eds.). Plankton Stratigraphy, 1, 283-314. Cambridge Univ. Press.

JENKYNS H.C. (1970a) - Growth and disintegration of a carbonate platform. Neues Jb. Geol. Paläont. Mh., 6, 325-344.

JenKyns H.C. (1970b) - Submarine volcanism and the Toarcian Iron Pisolites of Western Sicily. Ecl. Geol. Helv., 63 (2), 549-572.

JENKYNS H.C. (1971) - Speculations on the Genesis of Crinoidal Limestones in the Tethyan Jurassic. Geologischen Rundschau, 60 (2), 471-488.

Lentini F., Carbone S. \& Catalano S. (1994) - Main structural domains of the Central Mediterranean Region and their Neogene tectonic evolution. Boll. Geof. Teor. e Appl., 36, 103-125.

MARTIRE L. \& BERTOK C. (2002) - The Jurassic margin of a platform and its Cretaceous evolution. In: M. SANTANTONIO (Ed.), $6^{\circ} \mathrm{In}-$ ternational Simposium on the Jurassic System. General Field Trip Guidebook. 19-22 settembre 2002, 156-164, Palermo.

Martire L. \& Montagnino D. (2002) - A complex network of Jurassic to Miocene Neptunian Dykes. In: Santantonio M. (Ed.), $6^{\text {th }}$ International Symposium on the Jurassic System. General Field Trip Guidebook, pp. 87-91, 19-22 September 2002, Palermo.

Martire L., Bertok C., Pavia G. \& Sarti C. (2002) - Stop 11 Rocca Drago: Mesozoic pelagic sedimentation over the faulted margin of a pelagic platform. In: SANTANTONIO M. (Ed.), $6^{\text {th }}$ International Symposium on the Jurassic System. General Field Trip Guidebook, 91-96, 19-22 September 2002, Palermo.

MASClE G. (1973) - Geologie sur la structure de Rocca Busambra (Sicile occidentale): mise en èvidence d'une tectonique antècènomanienne. C.R. Acad. Sc. Paris, 276, 265-267.

Mascle G. (1979) - Etude Géologique des Monts Sicani. Riv. It. Paleont. Strat., 16, 1-430, Milano.

Monaco C., Mazzoli S. \& Tortorici L. (1996) - Active Thrust tectonics in western Sicily (southern Italy): the 1968 Belice earthquake sequence. Terra Nova, 8, 372-381.

Monaco C., Tortorici L. \& Catalano S. (2000) - Tectonic escape in the Sicanian mountains (western Sicily). Mem. Soc. Geol. It., 55, 17-25, $7 \mathrm{ff}$.

NigRo F. \& RENDA P. (1999) - Evoluzione geologica ed assetto strutturale della Sicilia centro-settentrionale. Boll. Soc. Geol. It., 118, 375-388.

Nigro F. \& RENDA P. (2001) - Oblique-slip thrusting in the Maghrebide chain of Sicily. Boll. Soc. Geol. It., 120, 187-200.
Ogniben L. (1960) - Note illustrative dello schema geologico della Sicilia Nord-Orientale. Riv. Min. Sic., 64-65, 183-212, 2 tavv. di sez. geol. 1:200.000. Palermo.

Oldow J.S., Channel J.E.T., Catalano R. \& D'Argenio B. (1990) - Contemporaneous Thrusting and Large-Scale rotations in the Western Sicilian Fold and Thrust Belt. Tectonics, 9 (4), 661-681.

Perch-Nielsen K. (1985) - Cenozoic calcareous nannofossils. In: Bolli H.M., Sanders J.B. \& Perch-Nielsen K. (Eds.), Plankton Stratigraphy, 1, 427-554. Cambridge University Press.

Roure F., Howell D.G., Muller C. \& Moretti I. (1990) - Late Cenozoic subduction complex of Sicily. Journ. of Structural Geology, 12 (2), 259-266.

Ruggieri G. (1966) - Appunti sul Miocene della Sicilia occidentale. Riv. Min. Sic., 97-99, 18-24, Palermo.

SAlvador A. (1994) - International Stratigraphic Guide. A guide to stratigraphic classification, terminology and procedure. The International Union of Geological Sciences and the Geological Society of America (Eds.), 214 pp.

Sprovieri R., Di Stefano E. \& SPRovieri M. (1996) - High resolution chronology for Late Miocene Mediterranean stratigraphic events. Riv. It. Paleont. Strat., 102, 77-104.

Sprovieri R., Bonomo S., Caruso A., Di Stefano A., Di Stefano E. Foresi M.L., IAccarino S.M., Lirer F., Mazzei R. \& SAlvaTORINI F. (2002) - An integrated calcareous plankton biostratigraphic scheme and biochronology for the Mediterranean middle Miocene. Riv. It. Paleont. Strat., 108, 337-353.

STAMPFly G.M. \& Borel G.D. (2002) - A plate tectonic model for the Palaeozoic and Mesozoic constrained by dynamic plate boundaries and restored synthetic oceanic isochrones. Earth and Planetary Science Letters, 169, 17-33.

TAmajo E. (1960) - Microfacies mesozoiche della Montagna della Busambra. Riv. Min. Sic., 63, 131-151, Palermo.

Vitale F.P. (1996) - Sezioni geologiche attraverso i Monti Sicani centro-occidentali. Dipart. di Geol. e Geod. La Tipolitografica s.n.c., Palermo 1996.

Vitale F.P. \& Giambrone C. (1995) - Sovrascorrimenti di tipo duplex nei Monti Sicani: l'esempio di Castronuovo (Sicilia centro occidentale). Natural. Sicil., S. IV, 16 (1-2), 39-62. Palermo.

WENDT J. (1963-1964) - Stratigraphisch-palaeontologische Untersuchungen im Dogger Westsizilien. Boll. Soc. Geol. Paleont. It., 2, $57-145$.

WENDT J. (1965) - Synsedimentare Bruchtektonik im Jura Westsizilien. Neus Jb. Geol. Paleont. Mh., 5, 286-311.

WENDT J. (1969) - Die stratigraphisch-paleographische Entwiklung des Jura im Westsizilien. Geol. Rdsch., 58, 735-755.

WENDT J. (1971) - Genese and fauna submariner sedimentaarer Spaltenfullungen im Mediterranean Jura. Palaeontographica, A (136), 122-192. 